\title{
Environmental adaptability and stress tolerance of Laribacter hongkongensis: a genome-wide analysis
}

Susanna KP Lau ${ }^{1,2,3,4^{*}+}$, Rachel YY Fan ${ }^{4 *}$, Tom CC Ho ${ }^{4}$, Gilman KM Wong ${ }^{4}$, Alan KL Tsang ${ }^{4}$, Jade LL Teng ${ }^{4}$, Wenyang Chen ${ }^{5}$, Rory M Watt ${ }^{5}$, Shirly OT Curreem ${ }^{4}$, Herman Tse ${ }^{1,2,3,4}$, Kwok-Yung Yuen 1,2,3,4 and Patrick CY Woo $1,2,3,4+$

\begin{abstract}
Background: Laribacter hongkongensis is associated with community-acquired gastroenteritis and traveler's diarrhea and it can reside in human, fish, frogs and water. In this study, we performed an in-depth annotation of the genes in its genome related to adaptation to the various environmental niches.

Results: L. hongkongensis possessed genes for DNA repair and recombination, basal transcription, alternative $\sigma$-factors and 109 putative transcription factors, allowing DNA repair and global changes in gene expression in response to different environmental stresses. For acid stress, it possessed a urease gene cassette and two arc gene clusters. For alkaline stress, it possessed six CDSs for transporters of the monovalent cation/proton antiporter-2 and $\mathrm{NhaC} \mathrm{Na}: \mathrm{H}^{+}$antiporter families. For heavy metals acquisition and tolerance, it possessed CDSs for iron and nickel transport and efflux pumps for other metals. For temperature stress, it possessed genes related to chaperones and chaperonins, heat shock proteins and cold shock proteins. For osmotic stress, 25 CDSs were observed, mostly related to regulators for potassium ion, proline and glutamate transport. For oxidative and UV light stress, genes for oxidant-resistant dehydratase, superoxide scavenging, hydrogen peroxide scavenging, exclusion and export of redox-cycling antibiotics, redox balancing, DNA repair, reduction of disulfide bonds, limitation of iron availability and reduction of iron-sulfur clusters are present. For starvation, it possessed phosphorus and, despite being asaccharolytic, carbon starvation-related CDSs.
\end{abstract}

Conclusions: The L. hongkongensis genome possessed a high variety of genes for adaptation to acid, alkaline, temperature, osmotic, oxidative, UV light and starvation stresses and acquisition of and tolerance to heavy metals.

\section{Background}

In 2001, Laribacter hongkongensis, a novel genus and species that belongs to the Neisseriaceae family of $\beta$-subclass of the Proteobacteria, was discovered from the blood and empyema pus of a patient with underlying alcoholic cirrhosis [1]. Subsequently, it was observed that L. hongkongensis was associated with communityacquired gastroenteritis and traveler's diarrhea in human [2-5]. L. hongkongensis is capable of living under a variety of ecological niches. In addition to humans,

\footnotetext{
* Correspondence: skplau@hkucc.hku.hk; rachelfyy2004@yahoo.com.hk † Contributed equally

'State Key Laboratory of Emerging Infectious Diseases, Hong Kong

${ }^{4}$ Department of Microbiology, The University of Hong Kong, Hong Kong

Full list of author information is available at the end of the article
}

L. hongkongensis resides in the intestines of a variety of freshwater fish, most commonly those of the carp family, including grass carps (Ctenoharyngodon idellus), bighead carps (Aristichthys nobilis) and mud carps (Cirrhina molitorella), as well as those of frogs [4,6-9]. Moreover, it can also survive and replicate as a free living bacterium in water obtained from drinking water reservoirs [10]. To survive in these ecological niches, L. hongkongensis needs the capability of protecting DNA damages by endogenous and exogenous metabolites and regulating the expression of a variety of genes, which makes it able to adapt to different temperatures, $\mathrm{pH}$ and osmotic pressures, as well as oxidative and ultraviolet light stresses.

\section{Biomed Central}

(c) 2011 Lau et al; licensee BioMed Central Ltd. This is an Open Access article distributed under the terms of the Creative Commons Attribution License (http://creativecommons.org/licenses/by/2.0), which permits unrestricted use, distribution, and reproduction in any medium, provided the original work is properly cited. 
In this article, we present an overview of the genes of the L. hongkongensis genome related to DNA repair and recombination and regulation of gene expression. In addition, the putative genes and mechanisms that enable L. hongkongensis to adapt to different temperatures, $\mathrm{pH}$ and osmotic pressures, as well as oxidative and ultraviolet light stresses were also presented. These genes of L. hongkongensis were compared to those of Neisseria gonorhoeae, Neisseria meningitidis and Chromobacterium violaceum, the other three bacteria of the Neisseriaceae family of $\beta$-proteobacteria with complete genome sequences available [11-13]. Human is the only known reservoir and host for $N$. gonorrhoeae and $N$. meningitidis. $N$. gonorrhoeae is most commonly associated with sexually transmitted infections and $N$. meningitidis is most commonly associated with pyogenic meningitis and bacteremia. C. violaceum is highly versatile and can be found abundantly in multiple ecosystems, including water and soil, in tropical and subtropical regions. It is associated with infrequent but potentially fatal infections in humans.

\section{Results and discussion DNA repair}

Several pathways are involved in the repair of mutagenic and cytotoxic effects of DNA damage that can arise through endogenous and exogenous stress in bacteria.

\section{Damage reversion (Direct repair)}

Reversion of the damaged base is the simplest DNA repair mechanism, which involves a single-step reaction by specific enzymes. Photoreactivation and alkylation repair are two of the most well-known damage reversion mechanisms. Photoreactivation is carried out by photolyase, which acts upon lesions induced by UV irradiation in a light-dependent reaction. A gene homologous to $p h r B$, which encodes a photolyase, was found in the L. hongkongensis genome (Table 1). Alkylation repair is mediated by the enzymes alkyltransferases, encoded by ogt and $a d a$, as well as iron-dependent dioxygenases, encoded by $a l k A$, which remove added alkyl groups from duplex DNA. Genes encoding for all three enzymes could be found in the L. hongkongensis genome (Table 1). Since L. hongkongensis can survive in natural water environments and is therefore often exposed to sunlight, these enzymes may be important for protection against such DNA damage. This is in contrast to $N$. meningitidis which lacks alk and some meningococcal and gonococcal strains which lack photolyase activity, which may reflect the lack of light exposure in the neisserial habitat [14].

\section{Base excision repair}

L. hongkongensis is exposed to reactive oxygen species generated during normal cellular metabolism, as well as from oxidative bursts from its host. One of the most important protective defense mechanisms against such DNA damage is the base excision repair (BER) pathway, which recognizes a wide range of DNA lesions. This includes the most frequently encountered form of oxidative DNA damage: production of 7, 8-dihydro-8-oxo-2'deoxyguanosine (8oxodG) which can lead to ambiguous base pairing (either A or $\mathrm{C}$ ) during DNA replication. The BER pathway is carried out by two types of enzymes: glycosylases and AP-endonucleases. Glycosylases excise the damaged base from the sugar phosphate backbone, leaving abasic (AP) sites, and endonucleases incise the 5' or 3' phosphodiester from the AP site to generate a nucleotide gap. There are eight glycosylases and endonucelases in the L. hongkongensis genome. Among the glycosylases, the uracil DNA glycocosylase (UNG) is the most well characterized enzyme found in various bacteria and eukaryotes. It is responsible for the excision of uracil residues from DNA which can arise as a result of misincorporation of dUMP residues by DNA polymerase or due to cytosine deamination. Similar to C. violaceum [15], the most closely related bacterial species of the Neisseriaceae family with complete genome sequence available, the L. hongkongensis genome contains two copies of UNG (Table 1). The complete 8oxodG system (GO system) is also present, which involves MutM/FPG, MutT and MutY, which act together to protect the bacterium against the effects of 8oxodG in E. coli [16]. MutM or FPG is formamidopyrimidine DNA glycosylase that recognizes oxidized purines such as 8oxodG and imidzole ring-opened purines; while MutY is an atypical glycosylase which removes adenine from DNA when it is mispaired with 8oxodG, preventing GC to TA transversions [17]. In N. meningitidis, it has been shown that MutY has a prominent role in DNA repair, with mut $Y$ mutants exhibiting high spontaneous mutation rates [14].

\section{Nucleotide excision repair}

Nucleotide excision repair (NER) involves a group of highly conserved proteins and repairs bulky lesions caused by exogenous damage such as UV light that generate a large helical distortion $[18,19]$. NER is carried out by the UvrABC complex in E. coli, which excises a 24- to 32-bp DNA fragment that contains the damaged lesion [20]. A functional NER pathway has also been demonstrated in $N$. gonorrhoeae [21]. Similar to N. gonorrhoeae, $N$. meningitidis and C. violaceum [14,15,21], homologues of all enzymes in this pathway are present in the L. hongkongensis genome (Table 1).

\section{Mismatch repair}

The mismatch repair (MMR) system recognizes and removes single-base mismatches as well as small nucleotide insertions or deletions (forming small loops) that result from errors during replication. In E. coli, MMR is carried out by a number of enzymes working at a 
Table 1 Single-strand breaks repair proteins in L. hongkongensis and their closest homologues

\begin{tabular}{|c|c|c|c|c|c|c|c|}
\hline $\begin{array}{l}\text { Repair pathways/ } \\
\text { Types of enzymes }\end{array}$ & Gene & Protein & Function of protein encoded & CDS & $\begin{array}{l}\text { Closest match } \\
\text { organism }\end{array}$ & $\begin{array}{l}\text { Amino acid } \\
\text { Identity (\%) }\end{array}$ & Best E-value \\
\hline \multicolumn{8}{|l|}{ Direct repair } \\
\hline & phrB & PhrB protein & $\begin{array}{l}\text { Repairs UV radiation-induced DNA damage by catalyzing light-dependent } \\
\text { monomerization of cyclobutyl pyrimidine dimers between adjacent bases }\end{array}$ & LHK_02646 & L. nitroferrum & 58.73 & $3.00 \mathrm{E}-131$ \\
\hline & ogt & Ogt & $\begin{array}{l}\text { Repairs alkylated guanine by transferring alkyl group at O- } 6 \text { position to a } \\
\text { cysteine residue in the enzyme }\end{array}$ & LHK_00364 & $\begin{array}{l}\text { Dechloromonas } \\
\text { aromatica }\end{array}$ & 46.67 & 4.00E-30 \\
\hline & ada & Regulatory protein Ada & $\begin{array}{l}\text { Repairs alkylated guanine in DNA by transferring alkyl group at the O- } 6 \\
\text { position to a cysteine residue in the enzyme }\end{array}$ & LHK_00147 & $\begin{array}{l}\text { Colwellia } \\
\text { psychrerythraea }\end{array}$ & 44.29 & $1.00 \mathrm{E}-60$ \\
\hline \multicolumn{8}{|l|}{ Base excision repair } \\
\hline \multirow[t]{4}{*}{ DNA glycosylases } & alkA & AlkA & $\begin{array}{l}\text { Excises damaged DNA polymer formed due to alkylation lesions by } \\
\text { hydrolyzing deoxyribose N-glycosidic bond }\end{array}$ & LHK_01743 & $\begin{array}{l}\text { Thiobacillus } \\
\text { denitrificans }\end{array}$ & 61.95 & $2.00 \mathrm{E}-62$ \\
\hline & mutY & MutY & $\begin{array}{l}\text { Adenine glycosylase active on G-A mispairs. Also corrects error-prone DNA } \\
\text { synthesis due to oxidized guanine }\end{array}$ & LHK_02781 & L. nitroferrum & 63.29 & 1.00E-92 \\
\hline & ung & UNG & $\begin{array}{l}\text { Excises uracil residues arised from misincorporation of dUMP residues by } \\
\text { DNA polymerase or cytosine deamination }\end{array}$ & LHK_00013 & L. nitroferrum & 56.14 & $3.00 \mathrm{E}-58$ \\
\hline & & & & LHK_00723 & $\begin{array}{l}\text { Ralstonia } \\
\text { pickettii }\end{array}$ & 59.26 & $2.00 \mathrm{E}-33$ \\
\hline \multirow[t]{2}{*}{$\begin{array}{l}\text { Bifunctional } \\
\text { glycosylases }\end{array}$} & $\begin{array}{l}\text { mutM } \\
\text { (fpg) }\end{array}$ & $\begin{array}{l}\text { Formamido-pyrimidine- } \\
\text { DNA glycosylase }\end{array}$ & $\begin{array}{l}\text { Recognizes and removes damaged bases. Cleaves DNA backbone to } \\
\text { generate single-strand break at site of base removal }\end{array}$ & LHK_00316 & $\begin{array}{l}\text { Neisseria } \\
\text { flavescens }\end{array}$ & 57.25 & $9.00 \mathrm{E}-90$ \\
\hline & nth & Endonuclease III & $\begin{array}{l}\text { Apurinic and/or apyrimidinic endonuclease activity and DNA N-glycosylase } \\
\text { activity }\end{array}$ & LHK_01218 & $\begin{array}{l}\text { Methylococcus } \\
\text { capsulatus }\end{array}$ & 72.04 & $1.00 \mathrm{E}-81$ \\
\hline \multirow[t]{2}{*}{ AP endonucleases } & $x \operatorname{th} A$ & Exodeoxyribo-nuclease III & Removes damaged DNA at cytosines and guanines & LHK_02447 & C. violaceum & 67.06 & 5.00E-94 \\
\hline & $\begin{array}{l}\operatorname{exOA} \\
(x \operatorname{thA2})\end{array}$ & Exodeoxyribo-nuclease & $\begin{array}{l}\text { Posseses } 3^{\prime} \text { to } 5^{\prime} \text { exonuclease, } 3^{\prime} \text { phosphatase activities and makes DNA } \\
\text { single-strand breaks at apurinic sites }\end{array}$ & LHK_03213 & L. nitroferrum & 73.73 & 1.00E-108 \\
\hline \multicolumn{8}{|l|}{$\begin{array}{l}\text { Nucleotide excision } \\
\text { repair }\end{array}$} \\
\hline \multirow[t]{3}{*}{$\begin{array}{l}\text { Global genome } \\
\text { repair factors }\end{array}$} & uvrA & Protein UvrA & $\begin{array}{l}\text { DNA-binding ATPase, forms recognition complex composed of } 2 \text { UvrA and } \\
2 \text { UvrB subunits and scans DNA for abnormalities }\end{array}$ & LHK_01605 & L. nitroferrum & 82.89 & 0 \\
\hline & $u v r B$ & Protein UvrB & $\begin{array}{l}\text { Causes local melting of the DNA helix, probes one DNA strand for the } \\
\text { presence of a lesion }\end{array}$ & LHK_00960 & L. nitroferrum & 82.18 & 0 \\
\hline & uvrC & Protein UvrC & Incises $5^{\prime}$ and $3^{\prime}$ sides of lesion & LHK_02627 & L. nitroferrum & 71 & 0 \\
\hline \multicolumn{8}{|c|}{$\begin{array}{l}\text { Transcription coupled repair } \\
\text { factors }\end{array}$} \\
\hline \multirow{5}{*}{$\begin{array}{l}\text { DNA-directed RNA } \\
\text { polymerase (RNAP) } \\
\text { complex }\end{array}$} & rpoB & RNAP subunit beta & Subunit of DNA-dependent RNA polymerase & LHK_00246 & L. nitroferrum & 85.26 & 0 \\
\hline & rpoC & RNAP subunit beta & Subunit of DNA-dependent RNA polymerase & LHK_00247 & C. violaceum & 87.09 & 0 \\
\hline & rpoA & RNAP subunit alpha & Subunit of DNA-dependent RNA polymerase & LHK_00279 & L. nitroferrum & 90.83 & $1.00 \mathrm{E}-171$ \\
\hline & rpoE & RNAP delta factor & Participates in initiation and recycling phases of transcription & LHK_01458 & L. nitroferrum & 63.82 & 7.00E-54 \\
\hline & rpoZ & RNAP omega subunit & Promotes RNA polymerase assembly & LHK_00457 & $\begin{array}{l}\text { Methylobacillus } \\
\text { flagellatus }\end{array}$ & 73.91 & $1.00 \mathrm{E}-21$ \\
\hline
\end{tabular}


Table 1 Single-strand breaks repair proteins in L. hongkongensis and their closest homologues (Continued)

\begin{tabular}{|c|c|c|c|c|c|c|c|}
\hline $\begin{array}{l}\text { Transcription-repair } \\
\text { coupling factor } \\
\text { (TRCF) }\end{array}$ & $m f d$ & TRCF & $\begin{array}{l}\text { Recognizes RNAP-DNA-RNA complex blocked at template strand lesion, } \\
\text { replaces RNAP, releases truncated transcript and recruits UvrABC repair } \\
\text { system }\end{array}$ & LHK_00629 & L. nitroferrum & 73.95 & 0 \\
\hline \multicolumn{8}{|l|}{$\begin{array}{l}\text { Mismatch excision } \\
\text { repair }\end{array}$} \\
\hline $\begin{array}{l}\text { Mismatch and loop } \\
\text { recognition factors }\end{array}$ & muts & $\begin{array}{l}\text { DNA mismatch repair } \\
\text { protein MutS }\end{array}$ & Mismatch recognition & LHK_00373 & C. violaceum & 67.73 & 0 \\
\hline $\begin{array}{l}\text { Molecular } \\
\text { matchmarker }\end{array}$ & mutl & $\begin{array}{l}\text { DNA mismatch repair } \\
\text { protein MutL }\end{array}$ & $\begin{array}{l}\text { Promotes formation of a stable complex between two or more DNA- } \\
\text { binding proteins }\end{array}$ & LHK_01012 & C. violaceum & 55.51 & 0 \\
\hline \multirow[t]{2}{*}{ DNA exonucleases } & $x s e A$ & $\begin{array}{l}\text { Exodeoxyribo-nuclease } 7 \\
\text { large subunit }\end{array}$ & Bidirectionally degrades single-stranded DNA & LHK_01101 & C. violaceum & 59.51 & 4.00E-125 \\
\hline & $x s e B$ & $\begin{array}{l}\text { Exodeoxyribo-nuclease } 7 \\
\text { small subunit }\end{array}$ & Bidirectionally degrades single-stranded DNA & LHK_02322 & C. violaceum & 65.28 & $6.00 \mathrm{E}-20$ \\
\hline \multirow[t]{9}{*}{$\begin{array}{l}\text { DNA polymerase III } \\
\text { holoenzyme }\end{array}$} & dnaE & $\begin{array}{l}\text { DNA polymerase III } \\
\text { subunit alpha }\end{array}$ & Subunit of DNA polymerase & LHK_01389 & L. nitroferrum & 74.13 & 0 \\
\hline & $d n a N$ & $\begin{array}{l}\text { DNA polymerase III } \\
\text { subunit beta }\end{array}$ & Subunit of DNA polymerase, initiates replication & LHK_03241 & L. nitroferrum & 72.5 & $3.00 \mathrm{E}-131$ \\
\hline & holc & $\begin{array}{l}\text { DNA polymerase III } \\
\text { subunit chi }\end{array}$ & Subunit of DNA polymerase & LHK_01415 & C. violaceum & 50 & $2.00 \mathrm{E}-27$ \\
\hline & holA & $\begin{array}{l}\text { DNA polymerase III } \\
\text { subunit delta }\end{array}$ & $\begin{array}{l}\text { Subunit of DNA polymerase, interacts with gamma subunit to transfer beta } \\
\text { subunit on DNA }\end{array}$ & LHK_00117 & C. violaceum & 67.28 & 7.00E-79 \\
\hline & holB & $\begin{array}{l}\text { DNA polymerase III } \\
\text { subunit delta }\end{array}$ & Subunit of DNA polymerase & LHK_02696 & L. nitroferrum & 57.36 & $3.00 \mathrm{E}-75$ \\
\hline & dnaQ & $\begin{array}{l}\text { DNA polymerase III } \\
\text { subunit epsilon }\end{array}$ & $\begin{array}{l}\text { Subunit of DNA polymerase, a 3'-5' exonuclease posseses proofreading } \\
\text { function }\end{array}$ & LHK_00881 & C. violaceum & 71.74 & $6.00 \mathrm{E}-85$ \\
\hline & & & & LHK_01009 & C. violaceum & 62.7 & 4.00E-60 \\
\hline & & & & LHK_02526 & C. violaceum & 51.52 & $3.00 \mathrm{E}-105$ \\
\hline & dnax & $\begin{array}{l}\text { DNA polymerase III } \\
\text { subunits gamma and tau }\end{array}$ & $\begin{array}{l}\text { Subunits of DNA polymerase, tau subunit serves as scaffold in dimerization } \\
\text { of the core complex while gamma subunit interacts with delta subunit to } \\
\text { transfer beta subunit on DNA }\end{array}$ & LHK_00963 & C. violaceum & 82.17 & $2.00 \mathrm{E}-154$ \\
\hline \multirow[t]{4}{*}{ Other MMR factors } & dam & DNA adenine methylase & $\begin{array}{l}\text { Methylates DNA sequence GATC and protects DNA from cleavage by } \\
\text { restriction endonuclease }\end{array}$ & LHK_01749 & C. violaceum & 83.92 & $8.00 \mathrm{E}-131$ \\
\hline & & & & LHK_02602 & C. violaceum & 75 & $9.00 \mathrm{E}-113$ \\
\hline & & & & LHK_00398 & C. violaceum & 75 & $9.00 \mathrm{E}-113$ \\
\hline & $v s r$ & $\begin{array}{l}\text { Very short patch repair } \\
\text { protein }\end{array}$ & Endonuclease, nicks double-stranded DNA & LHK_03243 & $\begin{array}{l}\text { Limnobacter sp. } \\
\text { MED105 }\end{array}$ & 61.38 & $5.00 \mathrm{E}-48$ \\
\hline
\end{tabular}


sequential manner: MutS recognizes the mismatch; MutL is recruited and binds as a dimer; the bound MutS-MutL complex in turn recruits the MutH endonuclease; MutH nicks the nascent DNA strand, distinguishing it from the parental strand by its undermethylation of GATC sequences; MutU (also known as UvrD) and other exonucleases (such as RecJ or ExoI) mediate the removal of up to 1000 bases (upstream or downstream) of the strand that contain the lesion $[22,23]$. This strand is then repaired by the actions of DNA polymerase I. Similar to $N$. meningitidis and C. violaceum $[14,15]$, the L. hongkongensis genome contains the most important enzymes of the MMR pathway except that mutH is absent, suggesting that this gene has been lost in related bacterial lineages (Table 1). In $N$. meningitidis, it has been shown that mutS mutants had a significantly increased frequency of phase variation and moderate increases in the rate of missense mutations [24]. However, other mechanisms are likely involved in determining meningococcal mutability. Further studies are required to investigate if MutH function is not required or another protein carries out the MutH strand-specificity function in these bacteria of the Neisseriaceae family. In contrast to C. violaceum, $N$. meningitidis and $N$. gonorrhoeae which possess only one copy of the Dam protein, which is responsible for DNA methylation, the L. hongkongensis genome contains three copies of dam. These three Dam homologues are phylogenetically most closely related to the Dam of C. violaceum, with two of the three copies having identical nucleotide sequences encoded on two highly similar prophages (Figure 1). It has previously been reported that the Dam methylase from $C$. violaceum has high similarity to a bacteriophage Dam homologue, suggesting acquisition via a horizontal transfer event [15]. Although our analysis shows that the Dam proteins from L. hongkongensis and C. violaceum are only distantly related to homologues found in other bacteriophages, the phylogenetic clustering of enzymes from different classes of bacteria supports that this enzyme is frequently horizontally transferred between bacteria (Figure 1).

\section{Recombinational repair}

Recombinational repair is activated in response to double-strand breaks (DSBs) in DNA which can lead to broken chromosomes and cell death. Such damage is repaired by homologous recombination in a process known as double-strand break repair (DSBR); which involves initiation, strand pairing and exchange, branch migration and branch resolution. Similar to the pathogenic Neisseria species and C. violaceum [15,25,26], the L. hongkongensis genome possesses all the important genes in this pathway, including the $\operatorname{rec} A$ gene universally found in bacteria (Table 2). RecA has an important role in pathogenic Neisseria species, being involved in repeat-associated events, including those associated with pilus antigenic variation and transformation in $N$. meningitidis [25]. The L. hongkongensis genome contains two pathways for repair initiation (RecBCD and RecFOR), and two pathways for branch migration and

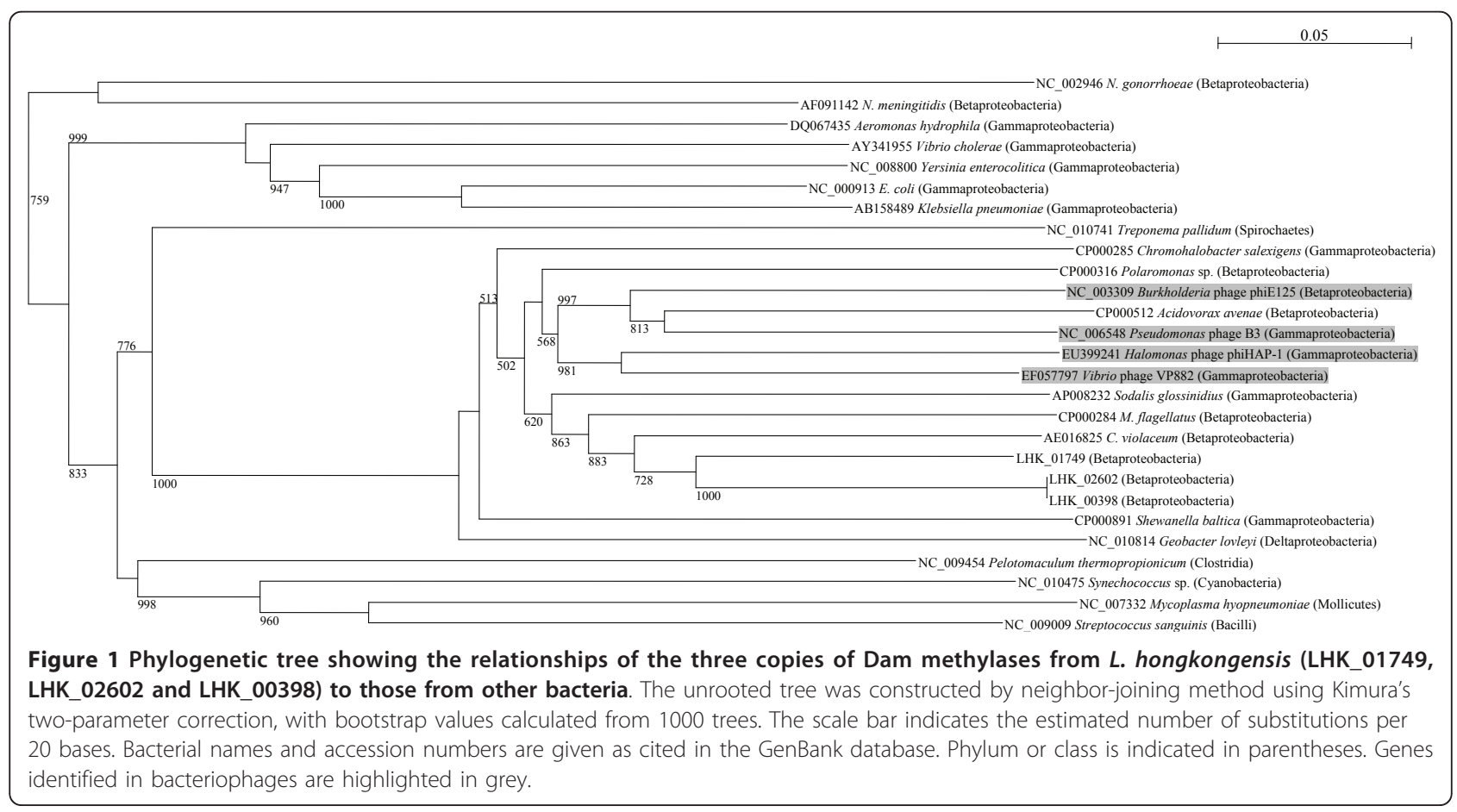


Table 2 Homologous recombination proteins in L. hongkongensis and their closest homologues

\begin{tabular}{|c|c|c|c|c|c|c|c|}
\hline $\begin{array}{l}\text { Repair pathways/ } \\
\text { Types of enzymes }\end{array}$ & Gene & Protein & Function of protein encoded & CDS & $\begin{array}{l}\text { Closest match } \\
\text { organism }\end{array}$ & $\begin{array}{l}\text { Amino acid } \\
\text { Identity (\%) }\end{array}$ & Best E-value \\
\hline \multicolumn{8}{|l|}{ Initiation } \\
\hline \multirow[t]{3}{*}{ RecBCD pathway } & $\operatorname{rec} B$ & $\begin{array}{l}\text { Exodeoxyribonuclease } \\
\vee \text { beta chain }\end{array}$ & $\begin{array}{l}\text { Catalyzes unwinding of double-stranded DNA and cleavage of } \\
\text { single-stranded DNA, stimulates local genetic recombination }\end{array}$ & LHK_01202 & $\begin{array}{l}\text { Pseudomonas } \\
\text { entomophila }\end{array}$ & 45.33 & 0 \\
\hline & recC & $\begin{array}{l}\text { Exodeoxyribonuclease } \\
V \text { gamma chain }\end{array}$ & $\begin{array}{l}\text { ATP-dependent exonuclease and helicase, DNA-dependent ATPase } \\
\text { and ATP-stimulated endonuclease }\end{array}$ & LHK_01203 & $\begin{array}{l}\text { Pseudomonas } \\
\text { aeruginosa }\end{array}$ & 48.11 & 0 \\
\hline & $r e c D$ & $\begin{array}{l}\text { Exodeoxyribonuclease } \\
\vee \text { alpha chain }\end{array}$ & $\begin{array}{l}\text { ATP-dependent exonuclease, ATPase and ATP-stimulated } \\
\text { endonuclease }\end{array}$ & LHK_01201 & Pseudomonas putida & 50.47 & 1.00E-126 \\
\hline \multirow[t]{4}{*}{ RecFOR pathway } & recF & $\begin{array}{l}\text { DNA replication and } \\
\text { repair protein RecF }\end{array}$ & DNA metabolism, DNA replication and normal SOS inducibility & LHK_01798 & Bordetella petrii & 43.67 & 4.00E-91 \\
\hline & reco & DNA repair protein $\mathrm{RecO}$ & Acts with RecF and RecR & LHK_01467 & L. nitroferrum & 50.41 & $6.00 \mathrm{E}-43$ \\
\hline & reck & $\begin{array}{l}\text { Recombination protein } \\
\text { RecR }\end{array}$ & Acts with RecF and RecO & LHK_00965 & L. nitroferrum & 70.71 & $5.00 \mathrm{E}-79$ \\
\hline & recQ & $\begin{array}{l}\text { ATP-dependent DNA } \\
\text { helicase RecQ }\end{array}$ & Helicase involved in the RecFOR recombination pathway & LHK_02771 & C. violaceum & 68.49 & 0 \\
\hline \multirow[t]{4}{*}{$\begin{array}{l}\text { Branch migration } \\
\text { and resolution }\end{array}$} & recG & $\begin{array}{l}\text { ATP-dependent DNA } \\
\text { helicase RecG }\end{array}$ & $\begin{array}{l}\text { Catalyzes branch migration in processing Holliday junction } \\
\text { intermediates to mature products. Unwinds DNA with a } 3^{\prime} \text { to } 5^{\prime} \\
\text { polarity }\end{array}$ & LHK_02776 & L. nitroferrum & 71.3 & 0 \\
\hline & ruvA & $\begin{array}{l}\text { Holiday junction ATP- } \\
\text { dependent DNA helicase } \\
\text { RuvA }\end{array}$ & $\begin{array}{l}\text { Forms complex with RuvB, RuvAB is a helicase that mediates } \\
\text { Holliday junction migration by localized denaturation and } \\
\text { reannealing }\end{array}$ & LHK_03111 & C. violaceum & 59.7 & $1.00 \mathrm{E}-54$ \\
\hline & $r u v B$ & $\begin{array}{l}\text { Holiday junction ATP- } \\
\text { dependent DNA helicase } \\
\text { RuvB }\end{array}$ & $\begin{array}{l}\text { Possesses weak ATPase activity, stimulated by the RuvA protein in } \\
\text { the presence of DNA. Forms complex with RuvA }\end{array}$ & LHK_00086 & L. nitroferrum & 92.35 & $8.00 \mathrm{E}-165$ \\
\hline & ruve & $\begin{array}{l}\text { Crossover junction } \\
\text { endodeoxyribonuclease } \\
\text { RuvC }\end{array}$ & $\begin{array}{l}\text { Resolves Holliday junction intermediates in recombination, cleaves } \\
\text { cruciform structure in supercoiled DNA }\end{array}$ & LHK_03190 & L. nitroferrum & 79.89 & $6.00 \mathrm{E}-58$ \\
\hline \multirow{8}{*}{$\begin{array}{l}\text { Other recombination } \\
\text { repair related } \\
\text { proteins }\end{array}$} & priA & Primosomal protein $\mathrm{N}^{\prime}$ & $\begin{array}{l}\text { Replication restart protein, catalyzes reactivation of replication forks } \\
\text { that have stalled at sites of DNA damage }\end{array}$ & LHK_02821 & L. nitroferrum & 58.37 & 0 \\
\hline & $\operatorname{rad} A$ & $\begin{array}{l}\text { DNA repair and } \\
\text { recombination protein } \\
\text { RadA }\end{array}$ & $\begin{array}{l}\text { Binds and assembles on single-stranded DNA, promotes DNA strand } \\
\text { exchange between homologous DNA molecules }\end{array}$ & LHK_02039 & L. nitroferrum & 79.42 & 0 \\
\hline & rusA & $\begin{array}{l}\text { Crossover junction } \\
\text { endodeoxyribonuclease } \\
\text { RusA }\end{array}$ & $\begin{array}{l}\text { Resolves Holliday junction intermediates made during homologous } \\
\text { genetic recombination and DNA repair }\end{array}$ & LHK_01785 & Ralstonia eutropha & 62.04 & $3.00 \mathrm{E}-40$ \\
\hline & rdgC & $\begin{array}{l}\text { Recombination-associated } \\
\text { protein RdgC }\end{array}$ & $\begin{array}{l}\text { Inhibits RecA promoted DNA strand exchange, ATPase activity, and } \\
\text { RecA-dependent LexA cleavage, a potential negative regulator of } \\
\text { RecA }\end{array}$ & LHK_00720 & L. nitroferrum & 58.92 & $3.00 \mathrm{E}-92$ \\
\hline & $\operatorname{rec} X$ & Regulatory protein $\operatorname{Rec} X$ & Inhibits RecA recombinase and coprotease activities & LHK_00794 & $\begin{array}{l}\text { Burkholderia } \\
\text { phymatum }\end{array}$ & 52.45 & $8 \mathrm{E}-25$ \\
\hline & yagF & $\begin{array}{l}\text { Putative Holliday junction } \\
\text { resolvase }\end{array}$ & Nuclease resolves Holliday junction intermediates & LHK_02882 & L. nitroferrum & 66.67 & $8 \mathrm{E}-46$ \\
\hline & bet & $\begin{array}{l}\text { Single-stranded DNA } \\
\text { annealing protein }\end{array}$ & $\begin{array}{l}\text { Mediates annealing of (partially) single-stranded regions of DNA } \\
\text { containing regions of complementary sequence }\end{array}$ & LHK_01498 & Providencia rettgeri & 69 & $9 \mathrm{E}-74$ \\
\hline & exo & Alkaline exonuclease & $\begin{array}{l}\text { Single-stranded DNA exonuclease that digests double-stranded DNA } \\
\text { ends with 5'- to 3'-polarity to generate long 3'-ssDNA ends }\end{array}$ & LHK_01497 & $\begin{array}{l}\text { Klebsiella pneumoniae } \\
\text { subsp. } \\
\text { rhinoscleromatis }\end{array}$ & 70 & $7 \mathrm{E}-76$ \\
\hline
\end{tabular}


resolution (RuvABC and RecG). In addition to recombination repair, the RecBCD and $\mathrm{RecN}$ are also involved in recombination during transformation, and $\mathrm{RecO}$, RecQ and RecJ in antigenic variation in $N$. gonorrhoeae $[25,27]$. However, it remains to be seen if these components possess similar function in related species including L. hongkongensis.

Interestingly, homologues of the Bet and Exo recombinational repair proteins from bacteriophage lambda are present within a probable $11 \mathrm{~kb}$ defective prophage region on the L. hongkongensis chromosome. Bet is a single-stranded DNA annealing protein (SSAP, sometimes also referred to as a synaptase), and Exo is a single-stranded DNA alkaline exonuclease with 5 ' - to 3'-polarity [28]. The bet and exo genes are positioned immediately adjacent to one another along with an additional copy of a single-stranded DNA binding protein of phage origin (ssb2, LHK_01496), which is homologous to, but distinct from, the presumed major functioning ssb of neisserial origin (LHK_01479). Such arrangements of phage-related DNA recombination proteins are commonly found in bacteria [29], acquired presumably by phage integration followed by subsequent genetic rearrangement. If actively transcribed, functional pairs of Exo and Bet proteins will promote DNA recombination events analogous to those mediated by the RecA/ RecBCD/RecFOR pathways, and would be expected to increase the rates of gene/genome rearrangements [28]. The Bet and Exo proteins may also function synergistically with RecA. The transcriptional status of the genes within this presumed defective prophage region remain to be established.

It has previously been noted that low-GC Gram positive species tend to possess RecT SSAPs rather than Bet-family proteins [29], although this relationship has not been re-examined more recently. The LHK_01498 gene is the only bet homologue present in the Neisseriaceae. However, there is a (functionally-equivalent) recT homologue present in Kingella oralis ATCC51147 (the only recT-family recombinase present in the Neisseriaceae) which does appear to have partnering exonuclease. Due to likely (partial) genetic reassortment in a phage host prior to incorporation into the L. hongkongensis genome, the bet, exo and ssb2 genes have apparently unrelated phylogenies (data not shown). The 162aa Ssb2 protein homologue is $69 \%$ identical to the presumed functional Ssb protein within the cell (175aa), but protein alignment reveals that it is lacking a stretch of ca. 25 amino acids near the C-terminus (data not shown). Interestingly, structural studies on the $E$. coli Ssb-DNA complex have shown that this unstructured region loops out from the $\mathrm{SsB}$ tetramer [30]. This region is not involved in DNA binding, but is thought to be responsible for interacting with the DNA primase and clamp loader proteins [31]. This suggests that the Ssb and Ssb2 proteins are designed to work with quite different replication or DNA repair protein systems.

\section{SOS Response}

The SOS response is activated when replication is blocked by DNA damage. The pathway is responsible for activation of a variety of physiological responses, including cell cycle inhibition and various DNA repair pathways. In E. coli, the SOS response involves more than 40 genes which are induced when there is a large amount of DNA damage, allowing increased repair and restoration of replication [32]. The pathway is controlled by a dual-component system, with RecA being the activator and LexA the repressor. The RecA protein forms a complex with single-stranded DNA, which leads to cleavage of LexA repressor and expression of the SOS regulon. Although genes related to SOS response, including $\operatorname{din} B, \operatorname{din} G, u m u-D$ and $\operatorname{dna} A$, could be identified, the lexA is absent in L. hongkongensis genome, a phenomenon also observed in C. violaceum, $N$. meningitidis and $N$. gonorrhoeae [14,15,33] (Table 3). This suggests that the $\operatorname{lex} A$ gene is lost in the common ancestor of these bacteria during evolution. Moreover, the recA, $u v r A$ and $u v r B$ genes of $N$. gonorrhoeae are known to lack the characteristic lexA-binding site or SOS boxes, the general hallmarks of an active SOS response. In fact, it is been experimentally confirmed that a functional SOS response is absent in $N$. gonorrhoeae [34]. Similarly, SOS boxes cannot be identified in the homologues of SOS-inducible genes in $N$. meningitidis $[14,35,12]$, suggesting that the SOS response may also be absent in related bacteria of the same family. Similar to the two Neisseria species and C. violaceum [15], SOS boxes are also absent in the SOS-related genes in L. hongkongensis. Further studies are required to determine if SOS response is constitutive or absent in this group of bacteria.

\section{DNA replication}

Bacterial DNA replication mechanisms are responsible for the accurate duplication of genetic material during cell division. The whole process involves the interplay of many different proteins with a variety of functions. A total of 36 coding sequences (CDSs) potentially involved in DNA replication are present in the L. hongkongensis genome, including 12 initiation factors, 11 elongation factors, 2 termination factors and 5 topoisomerases (Table 4). Since many of these proteins are essential to the bacterial cell and therefore preserved during bacterial evolution, they are often highly conserved among phylogenetically closely related bacteria.

\section{Replication initiation}

In L. hongkongensis, there is an oriC containing eight 9-bp repeat elements known as DnaA boxes, which are 
Table 3 Other proteins involved in DNA repair

\begin{tabular}{|c|c|c|c|c|c|c|c|}
\hline $\begin{array}{l}\text { Repair pathways/ } \\
\text { Types of enzymes }\end{array}$ & Gene & Protein & Function of protein encoded & CDS & $\begin{array}{l}\text { Closest } \\
\text { match } \\
\text { organism }\end{array}$ & $\begin{array}{l}\text { Amino acid } \\
\text { Identity (\%) }\end{array}$ & Best E-value \\
\hline
\end{tabular}

TLS (translesion DNA

synthesis) factors

ily DNA

dinB DNA Polymerase IV

polymerases

umuD Protein UmuD

Other SOS response

factors

$\operatorname{din} G$ Probable ATPdependent helicase DinG

dnaA Chromosomal replication initiator protein DnaA

Modulation of nucleotide pools

dut dUTPase

nrdA Ribonucleosidediphosphate reductas 1 subunit alpha

$\operatorname{nrdB}$ Ribonucleosidediphosphate reductase 1 subunit beta

nrdE Ribonucleosidediphosphate reductase 2 subunit alpha

mutT Mutator MutT protein

Other factors involved in ligA DNA ligase

DNA repair

Single-stranded-DNAspecific exonuclease Rec

polA DNA polymerase

ssb Single-stranded DNA binding protein, SSB

ssb2 Single-stranded DNA binding protein

$$
3 \mathrm{E}-57
$$

recA Protein RecA

recN DNA repair protein RecN

uvrD DNA helicase II

rep ATP-dependent DNA helicase Rep
Poorly processive, error-prone DNA polymerase involves in translesional DNA synthesis

Essential for induced (or SOS) mutagenesis, modifies DNA replication machinery to allow bypass synthesis across a damaged template

Damage-inducible helicase, unwinds DNA duplex with a $5^{\prime}-3^{\prime}$-polarity

Initiates and regulates chromosomal replication

LHK_01833 L. nitroferrum

69.32

2.00E-128

LHK_01580 Legionella pneumophila

subsp.

pneumophila

LHK 02134 L. nitroferrum

LHK_03240 L. nitroferrum

Produces dUMP, immediate precursor of thymidine nucleotides and decreases intracellular concentration of dUTP

Catalyzes biosynthesis of deoxyribo-nucleotides from the corresponding ribonucleotides

Catalyzes biosynthesis of deoxyribo-nucleotides from the corresponding ribonucleotides

LHK_01910 L. nitroferrum

LHK_01803 L. nitroferrum

Catalyzes biosynthesis of deoxyribo-nucleotides from the corresponding

LHK_01596 L. nitroferrum

79.73

0

Removes oxidatively damaged guanine from DNA and the nucleotide pool, LHK_02262 C. violaceum degrades 8-oxo-dGTP to monophosphate

Catalyzes phosphodiester linkages between 5'-phosphoryl and 3'-hydroxyl groups in double-stranded DNA, essential for DNA replication and repair

Single-stranded-DNA-specific exonuclease required for many

LHK_02877 Cupriavidus taiwanensis

LHK_02397 L. nitroferrum

$2.00 \mathrm{E}-56$ recombinational events

LHK_02983 C. violaceum

DNA polymerase exhibits $3^{\prime}$ to $5^{\prime}$ and $5^{\prime}$ to $3^{\prime}$ exonuclease activity

LHK_01479 M. flagellatus ssDNA from nucleolytic digestion and prevents secondary-structure formation

LHK_01496 L.

Forms a homotetramer and binds single-stranded DNA to protect susceptible ssDNA from nucleolytic digestion and prevents secondarystructure formation

Catalyzes ATP-dependent uptake of single-stranded DNA by duplex DNA, and hybridization of homologous single-stranded DNA

Coordinates alignment of broken segments with intact duplexes to facilitate LHK_01210 C. violaceum recombination

ATPase and helicase involves in post-incision events of nucleotide excision LHK_00065 C. violaceum repair and methyl-directed mismatch repair

Helicase and ATPase involves in DNA replication, binds to single-stranded LHK_00318 L. nitroferrum DNA, initiates unwinding at a nick 
Table 4 Replication proteins and their closest homologues

\begin{tabular}{|c|c|c|c|c|c|c|c|}
\hline $\begin{array}{l}\text { Types of } \\
\text { enzymes }\end{array}$ & Gene & Protein & Function of protein encoded & CDS & $\begin{array}{l}\text { Closest match } \\
\text { organism }\end{array}$ & $\begin{array}{l}\text { Amino acid } \\
\text { identity (\%) }\end{array}$ & Best E-value \\
\hline \multirow[t]{14}{*}{$\begin{array}{l}\text { Initiation } \\
\text { factors }\end{array}$} & hupB1 & $\begin{array}{l}\text { DNA-binding } \\
\text { protein hu-beta }\end{array}$ & $\begin{array}{l}\text { Beta chain of heterodimeric histone-like DNA-binding protein, wraps DNA to stabilize } \\
\text { and prevent denaturation under extreme environmental conditions }\end{array}$ & LHK_02345 & C. violaceum & 79.78 & $2.00 \mathrm{E}-33$ \\
\hline & hupB2 & $\begin{array}{l}\text { DNA-binding } \\
\text { protein hu-beta }\end{array}$ & $\begin{array}{l}\text { Beta chain of heterodimeric histone-like DNA-binding protein, wraps DNA to stabilize } \\
\text { and prevent denaturation under extreme environmental conditions }\end{array}$ & LHK_02180 & C. violaceum & 46.59 & $1.00 \mathrm{E}-14$ \\
\hline & $\begin{array}{l}\text { ihfA } \\
\operatorname{himA}\end{array}$ & $\begin{array}{l}\text { Integration host } \\
\text { factor subunit alpha }\end{array}$ & One of the two subunits of integration host factor, a specific DNA-binding protein & LHK_02751 & L. nitroferrum & 91.84 & $8.00 \mathrm{E}-46$ \\
\hline & $\begin{array}{l}i h f B / \\
\operatorname{himD}\end{array}$ & $\begin{array}{l}\text { Integration host } \\
\text { factor subunit beta }\end{array}$ & One of the two subunits of integration host factor, a specific DNA-binding protein & LHK_00870 & L. nitroferrum & 82.35 & $2.00 \mathrm{E}-39$ \\
\hline & $d n a A$ & $\begin{array}{l}\text { Chromosomal } \\
\text { replication initiator } \\
\text { protein DnaA }\end{array}$ & Initiates and regulates chromosomal replication & LHK_03240 & L. nitroferrum & 76.72 & 0 \\
\hline & $d n a B$ & $\begin{array}{l}\text { Replicative DNA } \\
\text { helicase }\end{array}$ & Initiation and elongation, DNA-dependent ATPase & LHK_01738 & C. violaceum & 76.48 & 0 \\
\hline & & & & LHK_01506 & N. gonorrhoeae & 40.73 & $3.00 \mathrm{E}-76$ \\
\hline & $d n a G$ & DNA primase & $\begin{array}{l}\text { Polymerase synthesizes small RNA primers for the Okazaki fragments on both } \\
\text { template strands at replication forks }\end{array}$ & LHK_00463 & C. violaceum & 65.42 & 2.00E-155 \\
\hline & ssb & $\begin{array}{l}\text { Single-stranded } \\
\text { DNA binding } \\
\text { protein, Ssb }\end{array}$ & $\begin{array}{l}\text { Forms homotetramer and binds single-stranded DNA to protect susceptible ssDNA } \\
\text { from nucleolytic digestion and prevents secondary-structure formation }\end{array}$ & LHK_01479 & M. flagellatus & 82.24 & 4.00E-46 \\
\hline & $s s b 2$ & $\begin{array}{l}\text { Single-stranded } \\
\text { DNA binding } \\
\text { protein }\end{array}$ & $\begin{array}{l}\text { Forms a homotetramer and binds single-stranded DNA to protect susceptible ssDNA } \\
\text { from nucleolytic digestion and prevents secondary-structure formation }\end{array}$ & LHK_01496 & $\begin{array}{l}\text { L. } \\
\text { hongkongensis } \\
\text { HLHK9 (Ssb } \\
\text { protein) }\end{array}$ & 68 & $3 \mathrm{E}-57$ \\
\hline & fis & $\begin{array}{l}\text { DNA-binding } \\
\text { protein Fis }\end{array}$ & Nucleoid-associated protein & LHK_03207 & C. violaceum & 73.68 & $1.00 \mathrm{E}-25$ \\
\hline & hvrA & H-NS like protein & Binds tightly to dsDNA, increases thermal stability and inhibits transcription & LHK_00853 & C. violaceum & 58.82 & $4.00 \mathrm{E}-28$ \\
\hline & & & & LHK_00959 & C. violaceum & 53.47 & $2.00 \mathrm{E}-18$ \\
\hline & $i c i A$ & $\begin{array}{l}\text { Chromosome } \\
\text { initiation inhibitor }\end{array}$ & In vitro inhibitor of chromosomal replication initiation & LHK_00797 & $\begin{array}{l}\text { Acinetobacter } \\
\text { baumannii }\end{array}$ & 43.24 & $1.00 \mathrm{E}-63$ \\
\hline \multirow[t]{8}{*}{$\begin{array}{l}\text { Elongation } \\
\text { factors }\end{array}$} & $d n a E$ & $\begin{array}{l}\text { DNA polymerase III } \\
\text { subunit alpha }\end{array}$ & Subunit of DNA polymerase & LHK_01389 & L. nitroferrum & 74.13 & 0 \\
\hline & $d n a N$ & $\begin{array}{l}\text { DNA polymerase III } \\
\text { subunit beta }\end{array}$ & Subunit of DNA polymerase, initiates replication & LHK_03241 & L. nitroferrum & 72.5 & $3.00 \mathrm{E}-131$ \\
\hline & holc & $\begin{array}{l}\text { DNA polymerase III } \\
\text { subunit chi }\end{array}$ & Subunit of DNA polymerase & LHK_01415 & C. violaceum & 50 & $2.00 \mathrm{E}-27$ \\
\hline & holA & $\begin{array}{l}\text { DNA polymerase III } \\
\text { subunit delta }\end{array}$ & $\begin{array}{l}\text { Subunit of DNA polymerase, interacts with gamma subunit to transfer beta subunit } \\
\text { on DNA }\end{array}$ & LHK_00117 & C. violaceum & 67.28 & 7.00E-79 \\
\hline & holB & $\begin{array}{l}\text { DNA polymerase III } \\
\text { subunit delta' }\end{array}$ & Subunit of DNA polymerase & LHK_02696 & L. nitroferrum & 57.36 & $3.00 \mathrm{E}-75$ \\
\hline & dnaQ & $\begin{array}{l}\text { DNA polymerse III } \\
\text { subunit epsilon }\end{array}$ & Subunit of DNA polymerase, a $3^{\prime}-5^{\prime}$ exonuclease possesses proofreading function & LHK_00881 & C. violaceum & 71.74 & $6.00 \mathrm{E}-85$ \\
\hline & & & & LHK_01009 & C. violaceum & 62.7 & 4.00E-60 \\
\hline & & & & LHK_02526 & C. violaceum & 51.52 & 3.00E-105 \\
\hline
\end{tabular}




\begin{tabular}{|c|c|c|c|c|c|c|c|}
\hline & dnax & $\begin{array}{l}\text { DNA polymerse III } \\
\text { subunits gamma } \\
\text { and tau }\end{array}$ & $\begin{array}{l}\text { Subunits of DNA polymerase, tau subunit serves as scaffold in dimerization of the } \\
\text { core complex while gamma subunit interacts with delta subunit to transfer beta } \\
\text { subunit on DNA }\end{array}$ & LHK_00963 & C. violaceum & 82.17 & $2.00 \mathrm{E}-154$ \\
\hline & $r n h A$ & Ribonuclease HI & $\begin{array}{l}\text { Endonuclease degrades RNA of RNA-DNA hybrids, specifies the origin of replication } \\
\text { by suppressing initiation at origins other than the oriC locus, removes RNA primers } \\
\text { from the Okazaki fragments of lagging strands }\end{array}$ & LHK_00880 & L. nitroferrum & 77.3 & 2.00E-59 \\
\hline & $r n h B$ & Ribonuclease HII & Endonuclease degrades RNA of RNA-DNA hybrids & LHK_00722 & L. nitroferrum & 71.88 & $1.00 \mathrm{E}-68$ \\
\hline & polA & DNA polymerase I & DNA polymerase exhibits $3^{\prime}$ to $5^{\prime}$ and $5^{\prime}$ to $3^{\prime}$ exonuclease activity & LHK_02983 & C. violaceum & 68.03 & 0 \\
\hline & $\operatorname{lig} A$ & DNA ligase & $\begin{array}{l}\text { Catalyzes phosphodiester linkages between 5'-phosphoryl and 3'-hydroxyl groups in } \\
\text { double-stranded DNA, essential for DNA replication and repair }\end{array}$ & LHK_02877 & C. taiwanensis & 65.83 & 0 \\
\hline \multirow[t]{4}{*}{$\begin{array}{l}\text { Termination } \\
\text { factors }\end{array}$} & dam & $\begin{array}{l}\text { DNA adenine } \\
\text { methylase }\end{array}$ & $\begin{array}{l}\text { Methylates DNA within the sequence GATC and protects the DNA from cleavage by } \\
\text { restriction endonuclease }\end{array}$ & LHK_01749 & C. violaceum & 83.92 & $8.00 \mathrm{E}-131$ \\
\hline & & & & LHK_02602 & C. violaceum & 75 & $9.00 \mathrm{E}-113$ \\
\hline & & & & LHK_00398 & C. violaceum & 75 & $9.00 \mathrm{E}-113$ \\
\hline & hda & $\begin{array}{l}\text { DnaA-homolog } \\
\text { protein hda }\end{array}$ & $\begin{array}{l}\text { Mediates interactions of DnaA with beta subunit sliding clamp, controls initiation of } \\
\text { DNA replication by inhibiting reinitiation of replication }\end{array}$ & LHK_00510 & C. violaceum & 66.82 & 1.00E-77 \\
\hline \multirow[t]{5}{*}{ Topoisomerases } & gyrA & $\begin{array}{l}\text { DNA gyrase subunit } \\
\text { A }\end{array}$ & $\begin{array}{l}\text { Negatively supercoils closed circular double-stranded DNA, catalyzes interconversion } \\
\text { of topological isomers of double-stranded DNA rings, including catenanes and } \\
\text { knotted rings. Consists of subunit A and B. Responsible for DNA breakage and } \\
\text { rejoining, forms A2B2 tetramer }\end{array}$ & LHK_01836 & L. nitroferrum & 82.09 & 0 \\
\hline & gyrB & $\begin{array}{l}\text { DNA gyrase subunit } \\
\text { B }\end{array}$ & $\begin{array}{l}\text { Negatively supercoils closed circular double-stranded DNA, catalyzes interconversion } \\
\text { of topological isomers of double-stranded DNA rings, including catenanes and } \\
\text { knotted rings. Consists of subunit A and B. Catalyzes ATP hydrolysis, forms A2B2 } \\
\text { tetramer }\end{array}$ & LHK_03242 & L. nitroferrum & 83.06 & 0 \\
\hline & parc & $\begin{array}{l}\text { DNA topoisomerse } \\
4 \text { subunit A }\end{array}$ & $\begin{array}{l}\text { Essential for chromosome segregation, relaxation of supercoiled DNA. Performs } \\
\text { decatenation during replication of circular DNA molecule. Composed of subunits } \\
\text { ParC and ParE }\end{array}$ & LHK_00093 & L. nitroferrum & 74.47 & 0 \\
\hline & parE & $\begin{array}{l}\text { DNA topoisomerase } \\
4 \text { subunit B }\end{array}$ & $\begin{array}{l}\text { Essential for chromosome segregation, relaxation of supercoiled DNA. Performs } \\
\text { decatenation during replication of circular DNA molecule. Composed of subunits } \\
\text { ParC and ParE }\end{array}$ & LHK_00606 & L. nitroferrum & 82.01 & 0 \\
\hline & topA & $\begin{array}{l}\text { DNA topoisomerase } \\
1\end{array}$ & Conversion of one DNA topological isomer to another & LHK_03143 & C. violaceum & 80.13 & 0 \\
\hline
\end{tabular}


potential binding sites for the initiator protein DnaA. The DnaA in L. hongkongensis is highly conserved when compared to those in closely related bacteria, with $76.7 \%$ amino acid identity with the homologue from Lutiella nitroferrum. The four domains of DnaA previously identified to possess distinct functions are also present [36]. As DnaA assembles with oriC to form a large nucleoprotein complex, the DNA melts to generate single DNA strands necessary for the binding of a helicase, DnaB, and the replisomal machinery [36]. Although bacteria do not possess histones, their genomes are arranged in tightly compacted arrangements known as nucleoids, which are important for maintaining an optimal DNA topology for replication initiation.

Six nucleoid-associated proteins, also referred to as histone-like factors, were identified in the L. hongkongensis genome, including two HU-beta proteins, one HN-S protein, two integration host factors (IHF) and one factor for inversion stimulation (Fis). HU-beta and HN-S proteins bind DNA non-specifically and contribute to the global condensation of bacterial chromosomes [37]. IHF and Fis recognize specific DNA sequences and assist in organizing supercoiled domains $[36,38]$. Earlier studies have shown that IHF stimulates DnaA-mediated unwinding of oriC, whereas Fis inhibits DUE melting $[39,40]$.

\section{Replication regulation}

The L. hongkongensis genome contains three copies of $d a m$ and one copy of the $h d a$ gene which are likely involved in the regulation of the replication process. Dam is an adenine methyltransferase responsible for the methylation of GATC sites of the oriC in E. coli which is important for origin sequestration, thus preventing reinitiation. Hda, a homologue of DnaA, is involved in the regulatory inactivation of DnaA (RIDA), which directly stimulates ATP hydrolysis by DnaA after the initiator melts the DUE [36]. It has been shown that $h d a$-deficient cells display an over-initiation phenotype in E. coli $[41,42]$.

\section{Control of gene expression}

As for other bacteria, the principal mechanism for control of gene expression is through regulation of the amount of mRNA produced from the corresponding gene. This is primarily determined by the affinity of RNA polymerase for the promoter. In L. hongkongensis, this is exemplified by the difference in mRNA levels of argB-20 and argB-37 at different temperatures, resulting in different amounts of the two enzymes, $\mathrm{N}$-acetyl-Lglutamate kinase (NAGK)-20 and NAGK-37 respectively [43]. Genes that encode proteins which control basal transcription, including the five-subunit RNA polymerase core enzyme $\left(\alpha_{2} \beta \beta^{\prime} \omega\right)$ and $\sigma$-factors for binding specifically to different classes of promoters and hence selective expression of different groups of genes, are present in the L. hongkongensis genome. The primary $\sigma$-factor, $\sigma^{70}$, is responsible for recognizing the promoters for transcription of most of the housekeeping genes. Furthermore, the L. hongkongensis genome contains other alternative $\sigma$-factors, including $\sigma^{28}$ (FliA), $\sigma^{32}$ $(\mathrm{RpoH}), \sigma^{38}$ (RpoS), $\sigma^{24}$ (RpoE) and $\sigma^{54}(\mathrm{RpoN})$, which allow it to bring about global changes in gene expression in response to different environmental stresses (Table 5). The types of alternative $\sigma$-factors in L. hongkongensis are the same as those in C. violaceum, except that there are two copies of $\sigma^{28}$ (the flagellar $\sigma$-factor) in the $C$. violaceum genome but only one copy of $\sigma^{28}$ in the L. hongkongensis genome. In the genomes of $N$. gonorrhoeae and N. meningitidis, no $\sigma^{28}$ and $\sigma^{38}$ (the starvation/stationary phase $\sigma$-factor) are observed. In addition to RNA polymerase and the $\sigma$-factors, the L. hongkongensis genome also encodes transcriptional activators and repressors, which belong to a variety of families of transcription factors. These transcription factors bind to sites near the target promoter and stimulate or repress the activity of the corresponding $\sigma$-RNA polymerase holoenzyme. In the L. hongkongensis genome, 109 coding sequences (CDSs) that encode putative transcription factors were identified (Table 6). Among the 46 families of bacterial transcription factors, L. hongkongensis contains genes that encode putative transcription factors in 22 of them. The largest groups belong to the LysR families. In most of the families, the number of genes in the L. hongkongensis genome that encode putative transcription factors in that family is in between that of $C$. violaceum and the Neisseria species (Table 7). This is in line with the ability of C. violaceum to survive in a wide range of environments and the fastidious growth requirements and limited host range of $N$. gonorrhoeae and N. meningitidis. One of the exceptions is that L. hongkongensis possesses three CDSs that encode putative transcription factors of the cold shock family, more than those in the genomes of $C$. violaceum, $N$. gonorrhoeae and N. meningitidis. This may be related to the adaptability of $L$. hongkongensis to environments of low temperatures, such as those of freshwater fish and frogs.

\section{Tolerance to acid stress}

L. hongkongensis is able to grow at $\mathrm{pH}$ of as low as 2 (unpublished data), and its tolerance to acid stress is much higher than that of N. gonorrhoeae, N. meningitidis and C. violaceum. This is in line with the recovery of $L$. hongkongensis from stool samples of patients with gastroenteritis, as it has to pass through the highly acidic environment of the stomach before reaching the intestine. Therefore, it is not surprising that L. hongkongensis possesses abundant mechanisms for tolerating 
Table 5 CDSs related to transcription in L. hongkongensis, N. meningitidis, N. gonorrhoeae and C. violaceum

\begin{tabular}{|c|c|c|c|c|c|}
\hline Product & Gene & $\begin{array}{l}\text { L. hongkongensis } \\
\text { HLHK } 9\end{array}$ & $\begin{array}{l}\text { N. meningitidis } \\
\text { MC58 }\end{array}$ & $\begin{array}{l}\text { N. gonorrhoeae } \\
\text { FA1090 }\end{array}$ & $\begin{array}{l}\text { C. violaceum } \\
\text { ATCC12472 }\end{array}$ \\
\hline ATP-dependent helicase & hrpA & + & + & + & + \\
\hline ATP-dependent RNA helicase & $r h I E$ & + & + & + & + \\
\hline DNA-directed RNA polymerase (alpha subunit) & rpoA & + & + & + & + \\
\hline DNA-directed RNA polymerase (beta subunit) & rpoB & + & + & + & + \\
\hline DNA-directed RNA polymerase (beta subunit) & rpoc & + & + & + & + \\
\hline DNA-directed RNA polymerase (omega subunit) & rpoZ & + & + & + & + \\
\hline RNA helicase & $d b p A$ & - & - & - & + \\
\hline Sigma factor 32 & rpoH & + & + & + & + \\
\hline Sigma factor 38 & rpos & + & - & - & + \\
\hline Sigma factor A (sigma 70) & $r p o D$ & + & + & + & + \\
\hline Sigma factor E (sigma 24) & rpoE & + & + & + & + \\
\hline Sigma factor for flagellar operon & fliA & + & - & - & $+^{a}$ \\
\hline Sigma factor N (sigma 54) & rpoN & + & + & + & + \\
\hline Transcription elongation factor GreA & greA & + & + & + & + \\
\hline Transcription elongation factor GreB & greB & + & + & + & + \\
\hline Transcription termination factor Rho & rho & + & + & + & + \\
\hline N utilization substance protein A & nusA & + & + & + & + \\
\hline $\mathrm{N}$ utilization substance protein $\mathrm{B}$ & nus $B$ & + & + & + & + \\
\hline Transcription anti-termination protein NusG & nus $G$ & + & + & + & + \\
\hline
\end{tabular}

${ }^{\mathrm{a}}$ Two copies of the gene are present

Table 6 Families of transcription factors (TFs) in $L$. hongkongensis

\begin{tabular}{|c|c|c|c|}
\hline Family & Number of TFs & Family & Number of TFs \\
\hline LysR & 25 & PadR & 0 \\
\hline AraC/Xyls & 9 & RpiR & 0 \\
\hline OmpR & 9 & ArgR & 0 \\
\hline $\mathrm{NtrC/Fis}$ & 8 & DtxR & 0 \\
\hline TetR & 8 & LexA & 0 \\
\hline $\mathrm{CRO} / \mathrm{Cl} /$ Xre & 8 & $\operatorname{TrmB}$ & 0 \\
\hline LuxR & 7 & PenR/Blal/Mecl & 0 \\
\hline GntR & 6 & SfsA & 0 \\
\hline ArsR & 4 & CopG/RepA & 0 \\
\hline MarR & 4 & ModE & 0 \\
\hline Cold shock domain & 3 & PaiB & 0 \\
\hline MerR & 3 & CtsR & 0 \\
\hline AsnC & 2 & CodY & 0 \\
\hline CRP-FNR & 2 & TrpR & 0 \\
\hline DeoR & 2 & MtIR & 0 \\
\hline Fur & 2 & ROS/MUCR & 0 \\
\hline BolA/YrbA & 2 & MetJ & 0 \\
\hline$|C| R$ & 1 & GutM & 0 \\
\hline Rrf2 & 1 & $\mathrm{Crl}$ & 0 \\
\hline LytTR & 1 & ComK & 0 \\
\hline $\mathrm{HrcA}$ & 1 & FlhD & 0 \\
\hline SirB & 1 & RtcR & 0 \\
\hline Lacl & 0 & NifT/FixU & 0 \\
\hline
\end{tabular}

acid stress compared to $N$. gonorrhoeae, $N$. meningitidis and C. violaceum.

The genome of L. hongkongensis contains a complete urease gene cassette and two arc gene clusters. The urease cassette contains eight CDSs encoding three structural (UreA, UreB and UreC) and five accessory proteins (UreE, UreF, UreG, UreD and UreI), whereas each arc cluster consists of four CDSs encoding the three enzymes, arginine deiminase, ornithine carbamoyltransferase and carbamate kinase, of the arginine deiminase pathway, and a membrane bound arginine-ornithine antiporter. Urease hydrolyzes urea into carbon dioxide and ammonia, whereas the arginine deiminase pathway converts L-arginine to carbon dioxide, ATP, and ammonia. The ammonia generated from both pathways raises the $\mathrm{pH}$ and counteracts the acid stress. A similar urease gene cassette is not present in the genomes of $N$. gonorrhoeae, $N$. meningitidis and $C$. violaceum, whereas one arc gene cluster is present in the $C$. violaceum genome, but not in that of N. gonorrhoeae or N. meningitidis.

In addition to the urease cassette and arc clusters, the L. hongkongensis genome also contains three CDSs that encode putative chaperones of which their transcription can also potentially be induced by acid shock. These include dnaK, mopA1 and htpG. Furthermore, other gene products may help the bacterium to survive in acidic environment or their expression can be induced by acid stress (Table 8 ). The functions of some of these 
Table 7 Distribution of transcription factors families in L.hongkongensis, N. meningitidis, N. gonorrhoeae and C. violaceum.

\begin{tabular}{|c|c|c|c|c|}
\hline Transcription factor family & L. hongkongensis HLHK9 & C. violaceum ATCC 12472 & N. gonorrhoeae FA 1090 & N. meningitidis MC58 \\
\hline AraC/Xyls & 9 & 25 & 3 & 3 \\
\hline ArsR & 4 & 4 & 4 & 2 \\
\hline AsnC & 2 & 6 & 2 & 2 \\
\hline Cold shock domain & 3 & 2 & 1 & 1 \\
\hline CRP-FNR & 2 & 3 & 1 & 1 \\
\hline DeoR & 2 & 4 & 1 & 1 \\
\hline GntR & 6 & 15 & 2 & 2 \\
\hline$|c| R$ & 1 & 2 & 1 & 1 \\
\hline Lacl & 0 & 2 & 0 & 0 \\
\hline LuxR & 7 & 12 & 1 & 1 \\
\hline LysR & 25 & 67 & 5 & 6 \\
\hline MarR & 4 & 18 & 2 & 3 \\
\hline MerR & 3 & 8 & 1 & 1 \\
\hline $\mathrm{NtrC} / \mathrm{Fis}$ & 8 & 19 & 4 & 3 \\
\hline OmpR & 9 & 11 & 1 & 1 \\
\hline TetR & 8 & 17 & 2 & 2 \\
\hline $\mathrm{CRO} / \mathrm{Cl} / \mathrm{Xre}$ & 8 & 9 & 12 & 9 \\
\hline Fur & 2 & 1 & 1 & 1 \\
\hline $\mathrm{HrCA}$ & 1 & 1 & 0 & 0 \\
\hline SirB & 1 & 1 & 1 & 1 \\
\hline Rif2 & 1 & 2 & 2 & 2 \\
\hline BolA/YrbA & 2 & 2 & 2 & 2 \\
\hline LytTR & 1 & 4 & 0 & 0 \\
\hline
\end{tabular}

gene products are unknown, but the survival of the respective bacteria at low $\mathrm{pH}$ had been shown to be affected if the corresponding gene was deleted [44-49].

\section{Tolerance to alkaline stress}

L. hongkongensis is able to grow at $\mathrm{pH}$ as high as 9.0 (unpublished data). While this may be related to its ability to survive the alkaline $\mathrm{pH}$ in the host intestine, growth at such alkalinity is still in line with many other non-extremophilic bacteria. Adaptive mechanisms to achieve cytoplasmic $\mathrm{pH}$ homeostasis in bacteria include transporters and enzymes that promote proton capture and retention, production of acidic metabolites and cell surface changes [50]. Among all these mechanisms, the most widely studied ones involve the transporters.

In the genome of $L$. hongkongensis, there are four CDSs coding for putative transporters which belong to the monovalent cation/proton antiporter-2 (CPA2) family. Two of the CDSs code for putative $\mathrm{Na}^{+} / \mathrm{H}^{+}$ exchangers (LHK_02296, LHK_00707) while the other two code for the putative genes kef (LHK_02848) and kefB (LHK_02018). No CDS encoding putative homologue of monovalent cation/proton antiporter-1 (CPA1) or monovalent cation/proton antiporter-3 (CPA3) has been identified. Transporters of the monovalent cation/proton antiporter (CPA) superfamily support key physiological functions of bacteria by catalyzing active efflux of $\mathrm{Na}^{+}$ and/or $\mathrm{K}^{+}$, with respective $\mathrm{H}^{+}$influx, to maintain cytoplasmic $\mathrm{pH}$ homeostasis and tolerate fluctuations in osmolarity [51]. Since cytoplasmic bacterial parasites or symbionts are sheltered by the host cell, it has been postulated that their genomes encode few genes for $\mathrm{Na}^{+} / \mathrm{H}^{+}$antiporters [51]. A comparison of L. hongkongensis, C. violaceum, intracellular pathogens $N$. gonorrhoeae and $N$. meningitidis, as well as the two model bacterial organisms, Bacillus subtilis and Escherichia coli, are shown in Table 9. It can be observed that L. hongkongensis and C. violaceum have more genes predicted to encode CPA2 superfamily transporters when compared to $N$. meningitidis and $N$. gonorrhoeae.

In addition to the four CDSs coding for the putative transporters of the CPA2 family, two CDSs putatively coding for transporters of the $\mathrm{NhaC} \mathrm{Na}^{+}: \mathrm{H}^{+}$antiporter (NhaC) family are also present (LHK_00646, LHK_02247) in the L. hongkongensis genome. Both are predicted to code for the gene $n h a C$. Nevertheless, gene sequences of the two CDSs are significantly different, indicating a possible difference in phylogenetic origin. The $n h a C$ homologue in the alkaliphilic bacteria Bacillus firmus has been confirmed experimentally to produce $\mathrm{NhaC}$, which has $\mathrm{Na}^{+} / \mathrm{H}^{+}$antiporter activity [52]. Table 9 also compares the number of identified NhaA, NhaB, NhaC and NhaD 
Table 8 Other CDSs related to acid stress in L.hongkongensis, $N$. meningitidis, $N$. gonorrhoeae and C. violaceum.

\begin{tabular}{|c|c|c|c|c|c|}
\hline Product & Gene & $\begin{array}{l}\text { L. hongkongensis } \\
\text { HLHK9 }\end{array}$ & $\begin{array}{l}\text { N. meningitidis } \\
\text { MC58 }\end{array}$ & $\begin{array}{l}\text { N. gonorrhoeae } \\
\text { FA1090 }\end{array}$ & $\begin{array}{l}\text { C. violaceum } \\
\text { ATCC12472 }\end{array}$ \\
\hline Acid shock RNA protein & asr & $t^{a}$ & - & - & + \\
\hline $\begin{array}{l}\text { Acid-resistance protein, possible } \\
\text { chaperone }\end{array}$ & hdeA & $+^{a}$ & - & - & - \\
\hline Sigma factor 38 & rpos & + & - & - & + \\
\hline Ferric uptake regulator protein & fur & + & + & + & + \\
\hline DNA polymerase I & polA & + & + & + & + \\
\hline$\beta$-ketoacyl-ACP synthases II & $f a b F$ & + & + & + & + \\
\hline Lysine:cadaverine antiporter & $c a d B$ & + & - & - & + \\
\hline Arginine decarboxylase & $\operatorname{adi} A$ & + & - & - & + \\
\hline Ada transcriptional dual regulator & ada & - & - & - & + \\
\hline Lysine decarboxylase & cadA & - & - & - & + \\
\hline OmpR transcriptional dual regulator & ompR & - & + & + & + \\
\hline
\end{tabular}

${ }^{\mathrm{a}}$ Two copies of the gene are present

family transporters in the genomes of L. hongkongensis to those in C. violaceum, N. meningitidis, N. gonorrhoeae, B. subtilis and E. coli.

\section{Acquisition of and tolerance to heavy metals}

To adapt to natural freshwater, L. hongkongensis should be able to acquire essential heavy metal ions and expel them, or their toxic counterparts, when their levels reach toxicity. Many heavy metals belong to the transition elements. Their electronic configurations provide them with an exquisite ability to form complex compounds. Metal ions such as iron(II), cobalt(II), nickel(II) and copper(II) are essential to many physiological functions, yet are toxic at high concentrations. Certain species, such as silver(I), cadmium(II) and mercury(II), however, are relatively toxic to bacteria; the toxic complexes formed by these ions preclude their physiological use by common bacteria [53].

Iron

Iron is required by both prokaryotes and eukaryotes for the synthesis of important proteins such as cytochromes. Bacteria employ a variety of mechanisms to acquire iron, such as siderophore-mediated uptake, metal inorganic transport systems (MIT) and ATP-binding cassette $(\mathrm{ABC})$ transport systems.

No gene for siderophore production was found in the L. hongkongensis genome. Since heme-bound iron and iron-containing proteins may not be readily available outside of a host [54], transporter-mediated transport of ionic iron would be the probable mechanism of iron acquisition during the environmental persistence of L. hongkongensis. A locus coding for the periplasmic ferric iron binding protein $\mathrm{FbpA}$, permease $\mathrm{FbpB}$ and a putative iron-transport system ATP-binding protein is present (LHK_02634-02636). Putative homologous loci, containing three similar CDSs, is present in C. violaceum
(CV1908-1910), N. gonorrhoeae (NGO0215-0217) and N. meningitidis (NMB0632-0634). The gene coding for the putative iron-transport system ATP-binding protein in L. hongkongensis (LHK_02636) is probably homologous to the $\mathrm{fbpC}$ gene in $N$. meningitidis. The FbpABC system has been shown to be a specific ferric iron transport system with high affinity to $\mathrm{Fe}^{3+}$ in Haemophilus influenzae [55]. In addition, two CDSs are the putative homologues of the genes coding for the high-affinity $\mathrm{ABC}$ transport system for ferrous iron in E. coli (feoABC) are present in the L. hongkongensis (LHK_03044-03045). The two CDSs code for the putative homologues of feoA and feoB respectively. The putative homologue of feoB is also present in C. violaceum. No putative homologues of feoA or feoC are found in $N$. gonorrhoeae and N. meningitidis.

Nickel

Nickel is an essential component of urease, which is implicated in the acid tolerance of L. hongkongensis. The CorA and HoxN systems have been proposed as an important nickel and cobalt transport system in bacteria [53]. No putative CDS coding for genes of the CorA system is present in the L. hongkongensis genome, yet a CDS coding for a histidine-rich glycoprotein with functional domain of the high-affinity nickel transport protein NicO was identified (LHK_02812). The NicO protein is related to the NixA of the HoxN family, which has been implicated in the urease-dependent pathogenesis of Helicobacter pylori[56]. A locus of four CDSs coding for $\mathrm{dppB}, \mathrm{dppC}, \mathrm{dppD}$ and $\mathrm{dppF}$ (LHK_00939-00942) was found. They belong to an ABC transporter subfamily and are predicted to transport dipeptides, oligopeptides and nickel. The dppA homologue (LHK_00667) is located distant from the dppBCDF locus. This is in contrast to $C$. violaceum, where the CDS coding for the putative dppA gene is contiguous to the dppBCDF locus. This separation of dppA from the 
$\mathrm{dppBCDF}$ locus, however, is not unique; it is also observed in H. influenzae[57]. The relatively well-characterized nickel/cobalt resistance system Cnr [58] and nickel/cobalt/cadmium resistance system Ncc [59] find no direct homologous systems in the L. hongkongensis; whilst the putative gene coding for a protein of similar function, in terms of sequence homology and functional domains, is traced to a CDS which encodes the putative NolG efflux pump of the resistance-nodulation-cell division superfamily (LHK_02819). In addition, two CDSs coding for an ABC transporter for cobalt (LHK_0107701078) were found; it is uncertain whether this member of the nickel(II)-cobalt(II) uptake transporter (NiCoT) family may also transport nickel due to variations in the exact level of binding specificity [60]. Homologues of putative genes encoding dppA, dppBCDF (LHK_00667, LHK_00939-00942) and the histidine-rich glycoprotein (LHK_02812) were identified in the genome of C. violaceum but not published genomes of $N$. gonorrhoeae or $N$. meningitidis. No putative homologue of the locus containing genes coding for the $\mathrm{ABC}$ transporter for cobalt (LHK_01077-01078) was identified in C. violaceum, $N$. gonorrhoeae or $N$. meningitidis.

\section{Cobalt}

Cobalt is found in coenzyme $B_{12}$, which is responsible for methyl group transfer and rearrangement $[61,62]$. Apart from the HoxN and NiCoT described, three CDSs that encode a putative $\mathrm{ABC}$-type cobalt transport system (LHK_01956-01958) and one that codes for a putative magnesium and cobalt efflux protein (LHK_00289) were also found. No putative homologue of the ABC-type cobalt transport system was found in C. violaceum, $N$. meningitidis and $N$. gonorrhoeae. For the putative magnesium and cobalt efflux protein gene, putative homologues were found in $C$. violaceum, $N$. meningitidis and $N$. gonorrhoeae as corC.

\section{Cadmium}

A CDS coding for a cadmium-translocating P-type ATPase (CadA-1, LHK_00449) was found in the genome. CadA and CadA-like proteins have been implicated in the transport of various heavy metals include, but not limiting to, cadmium, cobalt, mercury, lead and zinc [53]; CadA has been shown to be responsible for the $\mathrm{Cd}^{2+}$ efflux in both Gram-positive bacteria such as Staphylococcus aureus[63] and Bacillus spp. [64]; and Gram-negative bacteria such as Ralstonia metallidurans [65]. It may also contribute to $\mathrm{Pb}^{2+}$ efflux [66]. cadA-1 is very similar to the $E$. coli gene $z n t A$, which has been shown to be responsible for the intrinsic resistance of E. coli to zinc and cadmium [67]. Probable homologues and paralogues of cadA-1 and CadA-like protein coding genes are present in $C$. violaceum as zntA and copA; in $N$. meningitidis and $N$. gonorrhoeae as putative transport ATPase genes.

\section{Copper}

A locus of two CDSs (LHK_03034-03035) coding for a putative copper translocating ATPase and a conserved heavy metal associated domain were also found in the genome. The putative copper translocating ATPase gene has a homologue, copA, in E. coli; copA in E. coli has been shown to be important in resistance to the toxic effects of copper, and is induced by silver and copper ions [68]. Putative homologues of this copper translocating ATPase gene (LHK_03035) are also present in C. violaceum (copA), N. meningitidis and N. gonorrhoeae.

\section{Tolerance to temperature stress}

L. hongkongensis inhabits the intestines of freshwater fish, frogs and human [4,6-9]. It is also able to survive freely in freshwater environment [10]. In contrast to human, the body temperatures of freshwater fish and frogs vary with the environmental temperature. The ability to survive in such a wide range of habitats is in line with its ability to survive from $15^{\circ} \mathrm{C}$ to $42^{\circ} \mathrm{C}$, although its growth rate is higher at higher temperatures [8]. In an experiment that examined the differential gene expression of L. hongkongensis at $20^{\circ} \mathrm{C}$ to $37^{\circ}$ $\mathrm{C}$ using proteomics study, we found that there were 12 differentially expressed protein spots involved in various functions [43]. Seven spots were more highly expressed at $20^{\circ} \mathrm{C}$ than at $37^{\circ} \mathrm{C}$ and five more highly expressed at $37^{\circ} \mathrm{C}$ than at $20^{\circ} \mathrm{C}$. Among these were NAGK-37 that was up-regulated at $37^{\circ} \mathrm{C}$ and NAGK-20 that was up-regulated at $20^{\circ} \mathrm{C}$. These two isoenzymes of NAGK catalyze the second step of the arginine biosynthesis pathway.

In addition to the differentially expressed genes detected by 2 -dimensional gel electrophoresis, the $L$. hongkongensis genome also contains other genes that could be of importance for adaptation to different temperatures. These include genes related to chaperones and chaperonins, heat shock proteins and cold shock proteins. Overall, the number of CDSs in the L. hongkongensis genome encoding putative chaperones and heat shock proteins is lower than that in C. violaceum, but higher than those in the Neisseria species (Table 10). This phenomenon is similar to that observed in the number of distribution of transcription factors in L. hongkongensis, $N$. gonorrhoeae, $N$. meningitidis and C. violaceum as described above. On the other hand, the $L$. hongkongensis genome possesses two copies of cspA which encodes cold shock transcription factor and one copy of cspD which encodes cold shock protein homologue (Table 10). There is only one copy of cspA in the genomes of $N$. gonorrhoeae, $N$. meningitidis and $C$. violaceum, whereas cspD is absent from the genomes of $N$. gonorrhoeae and N. meningitidis. 
Table 9 Cation/proton antiporters identified in L. hongkongensis, N. meningitidis, N. gonorrhoeae and C. violaceum; and the model bacterial organisms, B. subtilis and $E$. coli

\begin{tabular}{|c|c|c|c|c|c|c|}
\hline Features & $\begin{array}{l}\text { L. hongkongensis } \\
\text { HLHK9 }\end{array}$ & $\begin{array}{l}\text { N. meningitidis } \\
\text { MC58 }^{\mathrm{b}}\end{array}$ & $\begin{array}{l}\text { N. gonorrhoeae } \\
\text { FA } 1090^{\mathrm{b}}\end{array}$ & $\begin{array}{l}\text { C. violaceum } \\
\text { ATCC12472 }\end{array}$ & B. subtilis $168^{\mathrm{b}}$ & $\begin{array}{l}\text { E. coli K12- } \\
\text { MG1655 }\end{array}$ \\
\hline$\overline{\text { Genome size }(\mathrm{Mb})^{a}}$ & 3.17 & 2.27 & 2.15 & 4.75 & 4.22 & 4.64 \\
\hline Total no. of transporter proteins & 442 & 103 & 96 & 564 & 298 & 354 \\
\hline $\begin{array}{l}\text { No. of identified transporters per } \\
\text { Mb genome }\end{array}$ & 139 & 45.4 & 44.7 & 119 & 71.0 & 76.3 \\
\hline No. of cation/proton antiporters & 6 & 4 & 4 & 3 & 6 & 7 \\
\hline $\begin{array}{l}\text { Monovalent cation:proton } \\
\text { antiporter-1 (CPA1) family }\end{array}$ & 0 & 1 & 1 & 0 & 1 & 2 \\
\hline $\begin{array}{l}\text { Monovalent cation:proton } \\
\text { antiporter-2 (CPA2) family }\end{array}$ & 4 & 1 & 1 & 3 & 2 & 3 \\
\hline $\begin{array}{l}\text { Monovalent cation }\left(\mathrm{K}^{+} \text {or } \mathrm{Na}^{+}\right) \text {: } \\
\text { proton antiporter-3 }(\mathrm{CPA} 3) \text { family }\end{array}$ & 0 & 0 & 0 & 0 & $1^{c}$ & 0 \\
\hline $\mathrm{NhaA} \mathrm{Na}{ }^{+} \mathrm{H}^{+}$antiporter family & 0 & 0 & 0 & 0 & 0 & 1 \\
\hline $\mathrm{NhaB} \mathrm{Na}{ }^{+}: \mathrm{H}^{+}$antiporter family & 0 & 0 & 0 & 0 & 0 & 1 \\
\hline $\mathrm{NhaC} \mathrm{Na}^{+}: \mathrm{H}^{+}$antiporter family & 2 & 2 & 2 & 0 & 2 & 0 \\
\hline $\mathrm{NhaD} \mathrm{Na}^{+}: \mathrm{H}^{+}$antiporter family & 0 & 0 & 0 & 0 & 0 & 0 \\
\hline
\end{tabular}

${ }^{a}$ Genome size data obtained from www.ncbi.nlm.nih.gov/projects/genome/, calculations based on data from www.membranetransport.org and with updated number of transporters in our annotation

${ }^{\mathrm{b}}$ Retrieved from www.membranetransport.org

${ }^{c}$ Not listed on www.membranetransport.org, see Krulwich et. al.

\section{Tolerance to osmotic stress}

L. hongkongensis can survive in and adapt to a variety of ecological niches, including water and the intestines of freshwater fish, frogs and humans, with different osmotic stress. A total of 25 CDSs in the L. hongkongensis genome could be related to control of osmotic pressure (Table 11). Most of these CDSs encode proteins and their regulators for transport of potassium ion, proline and glutamate. Among the 25 CDSs, 11 of them are related to potassium ion transport (nine and two for potassium uptake and efflux respectively); whereas only nine CDSs present in the $C$. violaceum genome and three in the $N$. gonorrhoeae and $N$. meningitidis genomes are related to potassium ion transport (Table 11).

Table 10 CDSs related to temperature stress in L. hongkongensis, N. meningitidis, N. gonorrhoeae and C. violaceum

\begin{tabular}{|c|c|c|c|c|c|}
\hline Product & Gene & $\begin{array}{c}\text { L. hongkongensis } \\
\text { HLHK } 9\end{array}$ & $\begin{array}{l}\text { N. meningitidis } \\
\text { MC58 }\end{array}$ & $\begin{array}{l}\text { N. gonorrhoeae } \\
\text { FA } 1090\end{array}$ & $\begin{array}{l}\text { C. violaceum } \\
\text { ATCC } 12472\end{array}$ \\
\hline Chaperone Hsp40, co-chaperone with DnaK & dna」 & + & + & + & + \\
\hline Chaperone Hsp70, co-chaperone with DnaJ & dnak & + & + & + & + \\
\hline Co-chaperone GrpE & grpE & + & + & + & + \\
\hline Chaperone subunit of chaperonin GroEL-GroES & groEL & $+^{\mathrm{a}}$ & + & + & $t^{\mathrm{a}}$ \\
\hline Regulator subunit of chaperonin GroEL-GroES & groEs & $t^{\mathrm{a}}$ & + & + & $t^{\mathrm{a}}$ \\
\hline ATP-dependent protease specificity component and chaperone & $c \mid p A$ & + & + & + & + \\
\hline ClpB chaperone & $c l p B$ & + & + & + & + \\
\hline ClpP serine protease & $c l p P$ & + & + & + & + \\
\hline Hsc66 chaperone, member of Hsp70 protein family & $h s c A$ & + & + & + & + \\
\hline $\mathrm{Hsc} 20$ co-chaperone of $\mathrm{Hsc} 66$ & $h s c B$ & + & + & + & + \\
\hline Heat shock protein of Hsp90 family & $h t p G$ & + & - & - & + \\
\hline Heat shock protein, integral membrane protein & $h t p X$ & + & + & + & $t^{a}$ \\
\hline Molecular chaperone Hsp33 & hs/O & + & + & + & + \\
\hline ATPase component of the HsIVU protease & hsIU & + & - & - & + \\
\hline Peptidase component of the HsIVU protease & $h s / V$ & + & - & - & + \\
\hline Heat shock protein Hsp15 & $h s / R$ & + & + & + & + \\
\hline Cold shock transcription factor & $\operatorname{csp} A$ & $t^{a}$ & + & + & + \\
\hline Cold shock protein homologue & $\operatorname{csp} D$ & + & - & - & + \\
\hline
\end{tabular}

${ }^{\text {a }}$ Two copies of the gene are present 
Table 11 CDSs related to control of osmotic pressure in L. hongkongensis, C. violaceum, N. meningitidis and N. gonorrhoeae

\begin{tabular}{|c|c|c|c|c|c|c|}
\hline Product & Gene & Function & $\begin{array}{l}\text { L. hongkongensis } \\
\text { HLHK } 9\end{array}$ & $\begin{array}{l}\text { C. violaceum ATCC } \\
12472\end{array}$ & $\begin{array}{l}\text { N. meningitidis } \\
\text { MC58 }\end{array}$ & $\begin{array}{l}\text { N. gonorrhoeae } \\
\text { FA } 1090\end{array}$ \\
\hline Sodium/hydrogen exchanger & - & Sodium efflux, hydrogen influx & $\begin{array}{l}\text { LHK_00707 } \\
\text { LHK_02296 }\end{array}$ & $\begin{array}{l}\text { CV2903 } \\
\text { CV4147 }\end{array}$ & - & - \\
\hline Potassium uptake protein & $\operatorname{trk} A$ & Potassium uptake & LHK_01490 & - & NMB1614 & NGO1154 \\
\hline Potassium uptake protein & trkH & Potassium uptake & LHK_01488 & - & NMB0661 & NGO0230 \\
\hline Glutathione-regulated potassium-efflux system protein & kefB & Potassium efflux, hydrogen influx & LHK_02018 & CV3326 & NMB0209 & - \\
\hline Glutathione-regulated potassium-efflux system protein & kef & Potassium efflux, hydrogen influx & LHK_02848 & - & - & NGO1774 \\
\hline Potassium-transporting ATPase, A subunit & $k d p A$ & Potassium uptake & LHK_01572 & CV1599 & - & - \\
\hline Potassium-transporting ATPase, B subunit & $k d p B$ & Potassium uptake & LHK_01573 & CV1598 & - & - \\
\hline Potassium-transporting ATPase, C subunit & $k d p C$ & Potassium uptake & LHK_01574 & CV1597 & - & - \\
\hline $\begin{array}{l}\text { Osmosensitive potassium channel signal transduction histidine } \\
\text { kinase }\end{array}$ & $k d p D$ & $\begin{array}{l}\text { Protein kinase of two-component } \\
\text { regulatory system }\end{array}$ & LHK_01575 & CV1596 & - & - \\
\hline Two component transcriptional regulator & $k d p E$ & $k d p$ operon transcription regulation & LHK_01576 & CV1595 & - & - \\
\hline Potassium-transporting ATPase & $k d p F$ & Potassium uptake & - & - & - & - \\
\hline $\begin{array}{l}\text { ATP-sensitive inward rectifier potassium channel related } \\
\text { transmembrane protein }\end{array}$ & - & Potassium uptake & - & CV1109 & - & - \\
\hline Low affinity potassium transport system protein & kup & Potassium uptake & $\begin{array}{l}\text { LHK_01720 } \\
\text { LHK_00121 }\end{array}$ & $\begin{array}{l}\text { CV2731 } \\
\text { CV0573 }\end{array}$ & - & - \\
\hline Glucose-methanol-choline oxidoreductase & betA & Glycine betaine synthesis & - & - & - & - \\
\hline NAD-dependent betaine aldehyde dehydrogenase & betB & Glycine betaine synthesis & - & - & - & - \\
\hline High-affinity choline transport protein & betT & Choline uptake & LHK_01689 & CV4302 & NMB1277 & NGO0529 \\
\hline Large conductance mechanosensitive channel & mscl & Compatible solute efflux & LHK_02562 & CV1360 & - & - \\
\hline \multirow[t]{5}{*}{ Small conductance mechanosensitive channel } & mscs & Compatible solute efflux & LHK_01830 & CV0295 & NMB0042 & NGO1771 \\
\hline & & & LHK_01942 & CV2330 & NMB0213 & NGO2057 \\
\hline & & & LHK_02394 & CV2385 & & \\
\hline & & & LHK_02965 & CV2962 & & \\
\hline & & & & CV4288 & & \\
\hline Osmotically inducible lipoprotein & osmB & - & LHK_01892 & CV3209 & - & - \\
\hline Osmotically inducible lipoprotein & osmC & - & LHK_01612 & - & - & - \\
\hline Sodium glutamate symport carrier protein & glts & Sodium and glutamate uptake & - & CV1105 & NMB0085 & NGO1890 \\
\hline
\end{tabular}


Table 11 CDSs related to control of osmotic pressure in L. hongkongensis, C. violaceum, N. meningitidis and $\mathbf{N}$. gonorrhoeae (Continued)

Proton glutamate symport protein

\section{Proline/betaine transproter}

ABC-type proline/glycine betaine transport systems, ATPase Proline-specific permease

Osmoprotectant transport system substrate-binding protein

Osmoprotectant transport system permease protein

Osmoprotectant transport system ATP-binding protein

Outer membrane porin

Outer membrane porin

Osmolarity sensor protein

Transcriptional regulator

Aquaporin Z

Glycerol uptake facilitator protein

Glycerol kinase

Glycerol-3-phosphate regulon repressor

proP Proline glycine betaine and ectoine

Proline, glycine betaine and ectoine LHK_02126 uptake

proV Proline and glycine betaine uptake

proY Proline uptake

Osmoprotectants uptake

\section{Osmoprotectants uptake}

\section{Osmoprotectants uptake}

ompC Hydrophilic molecules uptake by passive

$$
\text { diffusion }
$$

ompF Hydrophilic molecules uptake by passive diffusion

envZ Protein kinase of two-component regulatory system

ompR ompC and ompF transcription regulation

aqpZ Water influx and efflux

glpF Glycerol and water uptake

glpK Protein kinase of regulatory system LHK_03100

glpR Repressor in glp operons transcription LHK_03101 regulation
CV1198

CV3409

CV1299

CV290

CV1197

CV1138

CV1195

CV4392

CV1194

CV1196

CV4393

CV4395

CV4394

CV3424

CV0217

CV0216

CV2864

CV0252

CV0251

CV0112

CV0136 
In addition to the $11 \mathrm{CDSs}$ related to potassium transport, five other CDSs encode mechanosensitive channel proteins. These channels allow a quick and transient increase in compensatory solute (e.g. proline and glutamate) flux out of bacterial cells in response to large turgor pressure generated by water influx due to osmotic downshock when the bacterial cells are transferred to environments of low osmolarity [69]. Interestingly, a bet $T$ gene that encodes a transport protein for choline uptake is present in the L. hongkongensis genome. However, the bet $A$ and $\operatorname{bet} B$ genes, that encode enzymes for metabolizing choline to glycine betaine, the osmotically active compound, are absent [70]. Similarly, the $g l p R$ and $g l p K$ genes are present. However, the $g l p F$ gene, another gene in the $g l p F K$ operon that encodes the glycerol uptake facilitator protein, is absent [71]. Therefore, the contributions of bet $T, g l p R$ and $g l p K$ and their corresponding choline and glycerol transport systems to tolerance of osmotic stress in L. hongkongensis are unknown. The expressions of two other CDSs, osmB and osmC, which encode two osmotically inducible lipoproteins, have been found to be affected by change in osmolarity in E. coli $[72,73]$. Both osmB and osmC are membrane proteins of unknown function. In E. coli, it was observed that deletion of osmC will render the bacterium more sensitive to oxidative stress because of its peroxidase activity [74].

\section{Tolerance to oxidative stress and ultraviolet light stress}

Oxidative stress on aerobic bacteria is mainly mediated by partially reduced oxygen species, or reactive oxygen species, most notably superoxide and hydrogen peroxide, that are inevitable by-products of aerobic metabolism. These reactive oxygen species can cause damage to DNA, proteins and membranes. As a result, all aerobic bacteria possess various mechanisms to scavenge superoxide and hydrogen peroxide [75], as well as to protect the cells from damaged by these reactive oxygen species. In most bacteria, inducible responses to superoxide stress and hydrogen peroxide stress are mediated through the transcription factors $\operatorname{SoxR}(S)$ and OxyR respectively, which command the induction of a battery of defensive proteins, including superoxide dismutase and catalase respectively [76].

In the L. hongkongensis genome, genes for oxidantresistant dehydratase $(f u m C, a c n A)$, superoxide scavenging $(\operatorname{sod} B)$, hydrogen peroxide scavenging $(a h p C, c p x)$, exclusion and export of redox-cycling antibiotics (acr $A$, $a c r B, t o l C)$, redox balancing $(n f n B)$, DNA repair ( $x t h A$, $n t h$, mutM, mut $Y$, mutT), reduction of disulfide bonds ( $\operatorname{tr} x A, \operatorname{tr} x B, g p x A, g s h A, g s h B, \operatorname{grx} A, \operatorname{grx} C, \operatorname{gor})$ [77], limitation of iron availability ( $b f r, d p s$, fur) and reduction of iron-sulfur clusters (fpr, yggX) are present (Table 12). Transcriptions of most of the genes are regulated by
SoxR(S) and/or OxyR transcription factors in other bacteria (Table 12) [78]. In addition, some genes may be regulated by other transcription factors, such as RpoS, FNR [79], Fur and Lrp [80,81]. Interestingly, $\operatorname{SoxR}(\mathrm{S})$ is not present in the genomes of $N$. gonorrhoeae, $N$. meningitidis and $N$. lactamica and the role of $\operatorname{SoxR}(\mathrm{S})$ is presumably taken up by other transcription factors [82]. Notably, SoxR(S) was also not found in the L. hongkongensis genome by BLASTp search.

In addition to oxidative stress, ultraviolet light is another environmental stress that damages the DNA of a bacterium. The genomes of $L$. hongkongensis, $C$. violaceum, N. gonorrhoeae and $N$. meningitidis all contain one copy of $p h r B$ which encodes a photolyase for direct repair of DNA; and one copy each of $u v r A, u v r B, u v r C$ and $u v r D$ in the nucleotide excision repair system.

\section{Starvation related CDSs}

L. hongkongensis is arguably fastidious: it is asaccharolytic, metabolizing none of the common sugars, requiring malate, adipate or caprate as its carbon source $[1,4,43]$; in the laboratory, its optimal growth requires brainheart infusion (BHI) instead of commonplace lysogeny broth (LB) (unpublished data). Thus the pivotal study published in 2007, describing the isolation of L. hongkongensis from six of the 10 surveyed drinking water reservoirs in Hong Kong, prompts inquiries into the mechanisms of survival and persistence of this bacterium in nutrient-poor environments [10]. In many natural waters, nutrients are scarce. An average of the reservoirs from which $L$. hongkongensis were isolated demonstrates such: the permanganate value, a surrogate for organic carbon content, had a yearly mean of 1.25 $\mathrm{mg} \mathrm{O}_{2} / \mathrm{L}$; ammoniacal nitrogen, $0.05 \mathrm{mg} \mathrm{N} / \mathrm{L}$; and total phosphorus, $0.015 \mathrm{mg} \mathrm{P} / \mathrm{L}$ [83]. This is in stark contrast with even so-called "minimal medium", in which the malate content measures $2000 \mathrm{mg} / \mathrm{L}$; ammoniacal nitrogen $9.0 \mathrm{mg} \mathrm{N} / \mathrm{L}$ and total phosphorus $17 \mathrm{mg} \mathrm{P} / \mathrm{L}$ [84]. Clearly, L. hongkongensis has exquisite adaptive abilities which enable its survival in environments such as the drinking water reservoirs.

\section{General starvation}

With limited nutrients, bacteria do not continue their exponential growth indefinitely. Instead, they move into the stationary phase; cells lose viability and enter the death phase; in prolonged periods of nutrient depletion, a resistant subpopulation survives and the extended stationary phase ensues [85]. To adapt to stress conditions as such, alternative sigma factors enable bacterial RNA polymerase to transcribe an alternative subset of its genes. In the stationary phase, the starvation/stationary phase sigma factor, $\sigma^{38}$, encoded by $r p o S$, is used to upregulate the expression of a number of genes. Some of these genes may be clustered with rpos: in 
Table 12 CDSs related to tolerance of oxidative stress in L. hongkongensis, C. violaceum, N. meningitidis and $N$. gonorrhoeae.

\begin{tabular}{|c|c|c|c|c|c|c|}
\hline Gene & Protein & Regulated by & L. hongkongensis HLHK9 & $\begin{array}{l}\text { C. violaceum } \\
\text { ATCC12472 }\end{array}$ & N. meningitidis MC58 & $\begin{array}{l}\text { N. gonorrhoeae } \\
\text { FA1090 }\end{array}$ \\
\hline \multicolumn{7}{|c|}{ Transcriptional regulator } \\
\hline soxR & SoxR & $\mathrm{H}_{2} \mathrm{O}_{2}, \mathrm{O}_{2}$ & - & CV2793 & - & - \\
\hline soxs & Soxs & SoxR & - & - & - & - \\
\hline $\operatorname{oxy} R$ & OxyR & $\mathrm{H}_{2} \mathrm{O}_{2}$ & LHK_02531 & CV3378 & NMB0173 & NGO1813 \\
\hline ohrR & $\begin{array}{l}\text { Organic hydroperoxide resistance } \\
\text { transcriptional regulator }\end{array}$ & Organic peroxides & - & CV0210 & - & - \\
\hline fnr & Fumarate/nitrate reductase regulator & $\mathrm{O}_{2}$ & LHK_00352 & CV3647 & NMB0380 & NGO1579 \\
\hline perR & PerR & $\mathrm{H}_{2} \mathrm{O}_{2}$ & - & - & NMB1266 & NGO0542 \\
\hline $\operatorname{lrp}$ & Leucine-responsive protein & Leucine & LHK_01860 & CV1913 & $\begin{array}{l}\text { NMB0573 } \\
\text { NMB1650 }\end{array}$ & $\begin{array}{l}\text { NGO1294 } \\
\text { NGO1407 }\end{array}$ \\
\hline \multicolumn{7}{|c|}{ Oxidant-resistant dehydratase isozymes } \\
\hline fumc & Fumarase C & SoxRS, RpoS, FNR & LHK_00495 & CV1120 & NMB1458 & NG01029 \\
\hline$a c n A$ & Aconitase A & SoxRS, FNR, Fur, RpoS & $\begin{array}{l}\text { LHK_02153 } \\
\text { LHK_02309 }\end{array}$ & $\begin{array}{l}\text { CV1121 } \\
\text { CV2054 }\end{array}$ & NMB0433 & - \\
\hline \multicolumn{7}{|c|}{ Superoxide scavenging } \\
\hline sodA & Manganese superoxide dismutase & SoxRS, FNR & - & - & - & - \\
\hline $\operatorname{sod} B$ & Iron superoxide dismutase & & LHK_01716 & $\begin{array}{l}\text { CV0867 } \\
\text { CV2504 }\end{array}$ & NMB0884 & NGO0405 \\
\hline sodC & Copper-zinc superoxide dismutase & $\mathrm{H}_{2} \mathrm{O}_{2}, \mathrm{RpoS}, \mathrm{FNR}$ & - & - & NMB1398 & - \\
\hline \multicolumn{7}{|c|}{ Hydrogen peroxide scavenging } \\
\hline ahpC & Alky hydroperoxide reductase & OxyR, PerR & LHK_00938 & CV3739 & - & - \\
\hline$a h p F$ & Alky hydroperoxide reductase & OxyR, PerR & - & - & - & - \\
\hline$c p x$ & Cytochrome c peroxidase & FNR & LHK_02666 & CV0300 & - & NGO1769 \\
\hline $\begin{array}{l}\text { catalase/ } \\
\text { peroxidase }\end{array}$ & Hydroperoxidase I & OxyR, RpoS & $\begin{array}{l}\text { LHK_01300 } \\
\text { LHK_02436 }\end{array}$ & - & - & - \\
\hline catalase & Hydroperoxidase II & $\mathrm{H}_{2} \mathrm{O}_{2}$, RpoS & LHK_01264 & CV3549 & NMB0216 & NGO1767 \\
\hline \multicolumn{7}{|c|}{ Exclusion and export of redox-cycling antibiotics } \\
\hline micF & Antisense RNA to porin OmpF & SoxRS, Lrp, OmpR & - & - & - & - \\
\hline \multirow[t]{3}{*}{$\begin{array}{l}a c r A-a c r B- \\
\text { tolC }\end{array}$} & Drug export system & SoxRS & $\begin{array}{l}\text { LHK_01426-LHK_01425- } \\
\text { LHK_01424 }\end{array}$ & $\begin{array}{l}\text { CV0435-CV0434- } \\
\text { CV0433 }\end{array}$ & $\begin{array}{l}\text { NMB1716-NMB1715- } \\
\text { NMB1714 }\end{array}$ & $\begin{array}{l}\text { NGO1365-NGO1364- } \\
\text { NGO1363 }\end{array}$ \\
\hline & & & $\begin{array}{l}\text { LHK_02129-LHK_02130- } \\
\text { LHK_02131 }\end{array}$ & $\begin{array}{l}\text { CV2240-CV2241- } \\
\text { CV2242 }\end{array}$ & & \\
\hline & & & $\begin{array}{l}\text { LHK_02929-LHK_02930- } \\
\text { LHK_02931 }\end{array}$ & & & \\
\hline \multicolumn{7}{|c|}{ Redox balancing } \\
\hline$n f n B$ & Nitroreductase & SoxRS & $\begin{array}{l}\text { LHK_01953 } \\
\text { LHK_03211 }\end{array}$ & CV2244 & NMB0804 & NGO0388 \\
\hline \multicolumn{7}{|l|}{ DNA repair } \\
\hline$x \operatorname{th} A$ & Exodeoxyribonuclease III & $\mathrm{H}_{2} \mathrm{O}_{2}$, RpoS & LHK_02447 & CV0877 & NMB0399 & NGO1561 \\
\hline nth & Endonuclease III & & LHK_01218 & CV3293 & NMB0533 & NGO0139 \\
\hline
\end{tabular}


Table 12 CDSs related to tolerance of oxidative stress in L. hongkongensis, C. violaceum, $N$. meningitidis and $\mathbf{N}$. gonorrhoeae. (Continued)

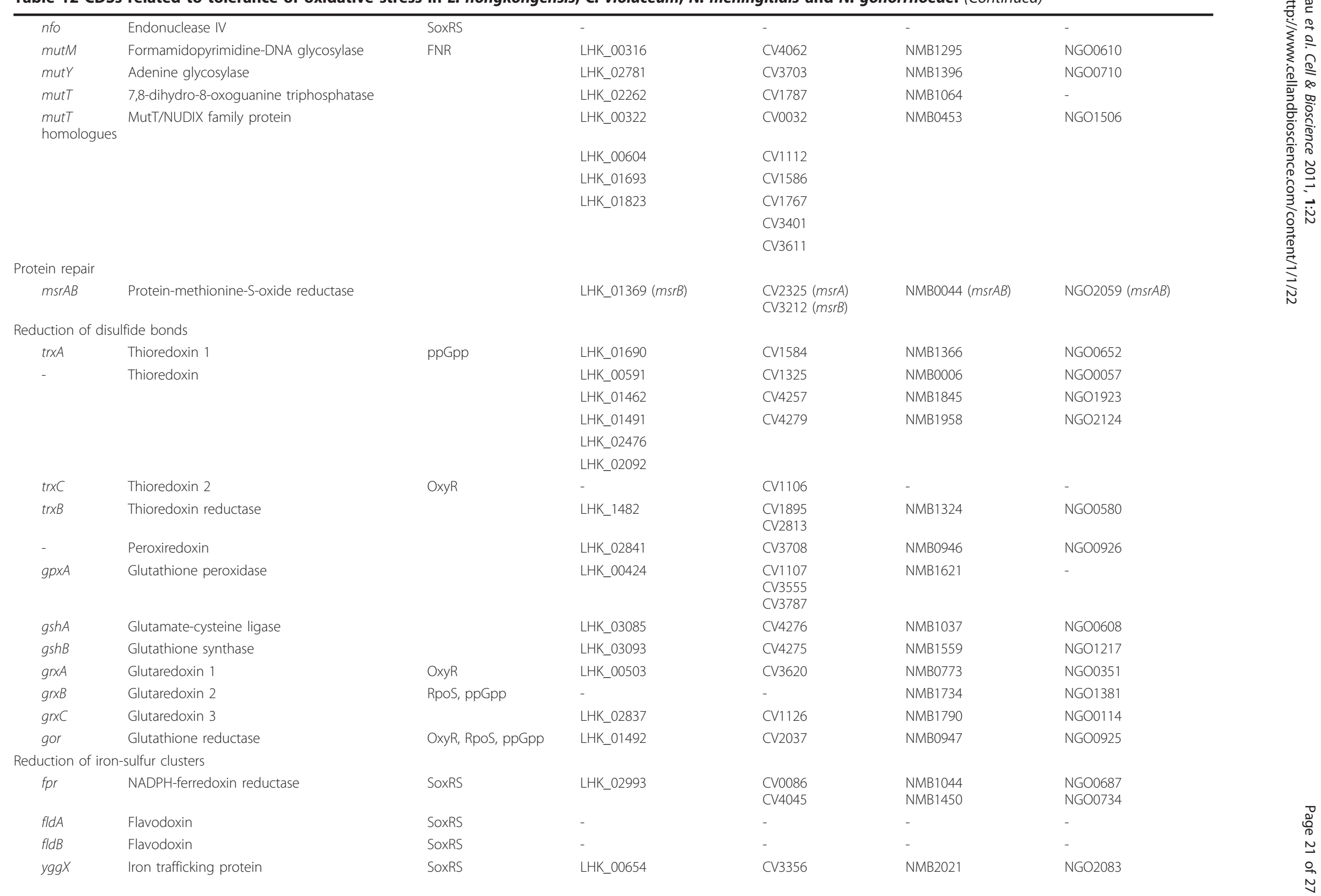


Table 12 CDSs related to tolerance of oxidative stress in L. hongkongensis, C. violaceum, $\mathbf{N}$. meningitidis and $\mathbf{N}$. gonorrhoeae. (Continued)

\begin{tabular}{|c|c|c|c|c|c|c|}
\hline \multicolumn{7}{|c|}{ Organic hydroperoxide resistance } \\
\hline ohrA & Organic hydroperoxide resistance protein & OhrR & - & CV0209 & - & - \\
\hline ohrB & Hydrogenperoxide resistance protein & Sigma B & - & CV2493 & - & - \\
\hline \multicolumn{7}{|c|}{ Disulfide bond formation in periplasm } \\
\hline$d s b A$ & Disulfide oxidoreductases & $\begin{array}{l}\text { Cpx two component } \\
\text { system }\end{array}$ & LHK_02939 & CV3998 & $\begin{array}{l}\text { NMB0278 } \\
\text { NMB0294 } \\
\text { NMB0407 }\end{array}$ & $\begin{array}{l}\text { NGO1548 } \\
\text { NGO1717 }\end{array}$ \\
\hline$d s b B$ & Oxidoreductase & & LHK_01744 & CV3193 & NMB1649 & NG01292 \\
\hline$d s b G$ & Thiol:disulfide interchange protein & OxyR & - & CV2637 & - & - \\
\hline \multicolumn{7}{|c|}{ Increase cellular pools of reduced pyridine nucleotides for glutathione-dependent repair reactions } \\
\hline$z w f$ & Glucose-6-phosphate 1-dehydrogenase & SoxRS & LHK_01919 & CV0145 & NMB1392 & NGO0715 \\
\hline \multicolumn{7}{|c|}{ Limit iron availability } \\
\hline$b f r$ & Bacterioferritin & Fur & LHK_01239 & $\begin{array}{l}\text { CV3399 } \\
\text { CV3552 }\end{array}$ & $\begin{array}{l}\text { NMB1206 } \\
\text { NMB1207 }\end{array}$ & $\begin{array}{l}\text { NGO0794 } \\
\text { NGO0795 }\end{array}$ \\
\hline$d p s$ & DNA-binding protein & OxyR, RpoS & $\begin{array}{l}\text { LHK_01835 } \\
\text { LHK_03179 }\end{array}$ & CV4253 & - & - \\
\hline fur & Ferric uptake regulator & PerR, OxyR, SoxRS & LHK_01431 & CV1797 & NMB0205 & NGO1779 \\
\hline \multicolumn{7}{|c|}{ Protein binding } \\
\hline hsIO & Molecular chaperone Hsp33 & $\mathrm{H}_{2} \mathrm{O}_{2}$ \& temperature & LHK_02184 & CV2000 & NMB2000 & NGO1189 \\
\hline \multicolumn{7}{|l|}{ Others } \\
\hline $\operatorname{rimk}$ & Ribosomal protein $\mathrm{S} 6$ modification protein & SoxRS & - & - & - & - \\
\hline ribA & Cyclic GMP hydrolase & SoxRS & LHK_02390 & CV2005 & NMB1254 & NGO1134 \\
\hline
\end{tabular}


L. hongkongensis a surE-pcm-nlpD-rpoS cluster was observed (LHK_00356-00353). This is similar to C. violaceum ATCC12472 (CV_3679-3682), and was also observed in other pathogens such as E. coli, Salmonella Typhimurium [86] and Yersinia pestis [87]. In the L. hongkongensis surE-pcm-nlpD-rpoS cluster, there is an overlap between the $s u r E$ and $p c m$ genes; which was also observed in C. violaceum. Despite this overlapping, as shown in $E$. coli, the $p c m$ gene can either be cotranscribed with the $s u r E$ gene or transcribed on its own [88].

A CDS coding for the putative gene surA precursor is present in the L. hongkongensis genome (LHK_03194). This survival protein precursor was also found in C. violaceum, N. meningitidis, $N$. gonorrhoeae and E. coli. SurA, the periplasmic chaperone protein encoded by this gene, is responsible for the proper folding and insertion of a subset of outer membrane proteins in E. coli [89]. It is of interest, however, to note that the SurA precursor protein is only expressed at $37^{\circ} \mathrm{C}$, but not the environmental temperature of $20^{\circ} \mathrm{C}$, when L. hongkongensis is cultured in the rich medium of $\mathrm{BHI}$ [43]. It is unknown, therefore, whether temperature may have a more generalized effect on the starvation response of L. hongkongensis.

\section{Carbon starvation}

In the L. hongkongensis genome, only one CDS coding for the putative carbon starvation gene cstA2 was found (LHK_00676). This is similar to N. gonorrhoeae and $N$. meningitidis, but different from the $C$. violaceum genome, which contains two CDSs coding for the putative genes $\operatorname{cst} A 1$ and $\operatorname{cst} A 2$. The $E$. coli homologue of the L. hongkongensis cstA 2 gene is cstA. CstA is a starvation-induced peptide transporter in $E$. coli, and has been implicated in peptide utilization [90].

CDSs coding for putative genes $\operatorname{ssp} A$ and $\operatorname{ssp} B$ are present in the L. hongkongensis genome (LHK02886-02887). Putative homologues of $\operatorname{ssp} A$ and $\operatorname{ssp} B$ are also present in $C$. violaceum, $N$. meningitidis, $N$. gonorrhoeae and E. coli. In $E$. coli, $s s p A$ and $s s p B$ code for the stringent starvation proteins SspA and SspB. Whilst SspA is essential to expression of $\mathrm{SspB}$, it has also been found to be upregulated in the starvation response to glucose, nitrogen, phosphate and amino acids [91]. SspA and SspB are probably not implicated in the sugar starvation response of L. hongkongensis, if any, since the bacterium is asaccharolytic. It is uncertain, nevertheless, whether carbon starvation, i.e. of malate, caprate and adipate, may lead to upregulation of the putative $\operatorname{ssp} A$ and $s s p B$ genes in L. hongkongensis.

\section{Phosphorus starvation}

It has long been observed that phosphate is often the limiting nutrient of algal and bacterial growth in freshwater environments [92-94]. Bacteria have evolved various mechanisms to enhance the uptake of phosphate, even by cell envelope elongation to increase the surface area to volume ratio [95]; albeit a relationship is yet to be ascribed to the seagull or spiral rod shape of L. hongkongensis. From the freshwater reservoir data stated above, phosphate is probably the scarcest nutrient amongst carbon, nitrogen, phosphorus and iron with its concentration of $0.015 \mathrm{mg} \mathrm{P} / \mathrm{L}$ ( or $0.5 \mu \mathrm{M}$ ). On the other hand, however, it is worthwhile to note the more recent finding that phosphate depletion may enhance bacterial resistance to multiple antimicrobials [96,97].

Phosphate homeostasis in bacteria is mainly achieved by the PhoR/PhoB two-component regulatory system (TCRS). In L. hongkongensis, the putative genes coding for the PhoR/PhoB are adjacent to each other (LHK_00166-00165), as in C. violaceum (CV_05630562). The $N$. gonorrhoeae and $N$. meningitidis homologue of the phoR and $p h o B$ genes, however, could not be identified.

The PhoR/PhoB TCRS is closely related to the phosphate-specific transport (Pst) system. In E. coli, there is a pstSCAB-phoU operon in which the genes pstS, pst $C$, pst $A$, pst $B$ and phoU are clustered. This is not the case in L. hongkongensis, C. vioalceum, N. gonorrhoeae and $N$. meningitidis. In L. hongkongensis, the putative pstSCAB locus (LHK00524-00521) is well separated from the CDS coding for the putative phoU gene (LHK_00885). In C. violaceum, this separation is also seen (pstSCAB: CV_0938-0935; phoU: CV_1261); the pstSCAB locus is also clustered with the putative pitA gene, which codes for a low-affinity inorganic phosphate transporter (CV_0934). In contrast to such, the CDS that encodes the putative pitA gene in $L$. hongkongensis is separated from the putative pstSCAB locus (LHK_02538). It is believed that the PstS, PstC, PstA and PstB proteins, together with PhoU, are responsible for the formation of an $A B C$ transporter in the capture of periplasmic inorganic phosphate. In an abundance of phosphate, the Pst system, together with the histidine kinase PhoR, repress the transcription regulatory protein PhoB. When the extracellular phosphate concentration is below a threshold value, for example $4 \mathrm{mM}$ in $E$. coli, autophosphorylation on a PhoR histidine residue occurs; the phosphorylation is subsequently transferred form phospho-PhoB, which modulates Pho regulon activities $[98,99]$.

\section{Conclusions}

The L. hongkongensis genome possessed a high variety of genes for DNA repair and recombination and regulation of gene expression, as well as adaptation to acid, alkaline, temperature, osmotic, oxidative, UV light and starvation stresses as well as acquisition of and tolerance to heavy metals (Figure 2) 


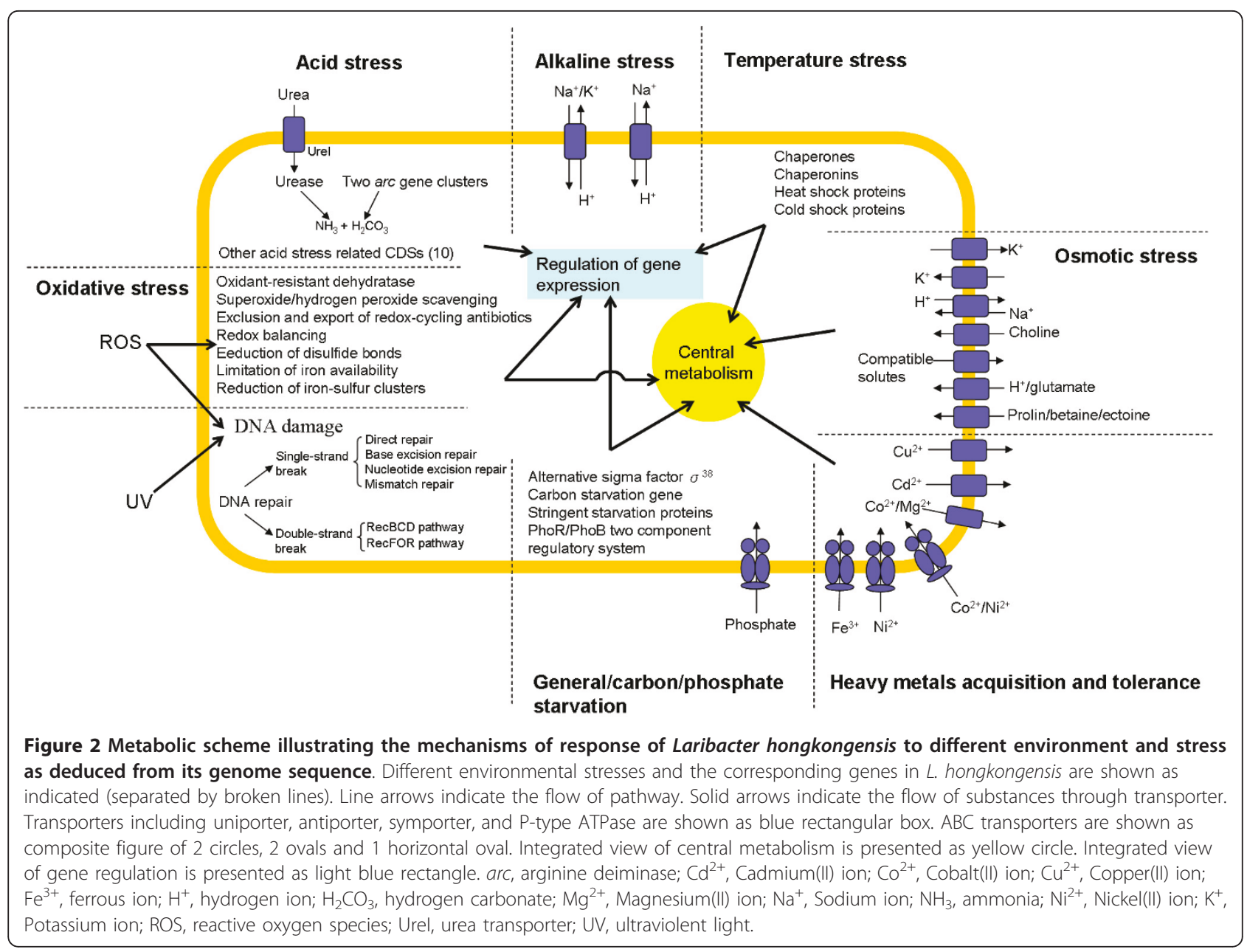

\section{Methods}

All CDSs in the L. hongkongensis genome were annotated as described in our previous publication and classified functionally according to the Clusters of Orthologous Groups system [43]. Annotated genes were mapped to pathways according to the Kyoto Encyclopedia of Genes and Genomes database to help identify stress-response pathways. The CDSs were members of COG L (replication, recombination and repair), COG $\mathrm{K}$ (transcription), COG F (nucleotide transport and metabolism) and COG O (post-translational modification, protein turnover, chaperones). Additional CDSs were examined by keyword search using the following words and their variants: stress response, regulation, adaptation, temperature, ultraviolet, acid, alkali, pressure, oxidative, homeostasis and resistance. Manual confirmation of the assigned function was performed by sequence similarity search using BLAST against the NCBI nr database, and assisted by conserved domain search (CD-search), identification of signature sequence motifs and sequence analysis using InterProScan. Cellular localization of putative proteins was predicted using PSORTb where appropriate [100]. Phylogenetic relationships were determined using Clustal $\times$ version 1.81 . oriC was predicted by Ori-finder http://tubic.tju.edu.cn/doric/.

\section{Abbreviations}

8oxodG: 7, 8-dihydro-8-oxo-2'-deoxyguanosine; o24 (RpoE): RNA polymerase sigma-E factor; $\sigma 28$ (FliA): RNA polymerase sigma factor for flagellar operon; $\sigma 32(\mathrm{RpoH})$ : RNA polymerase sigma-32 factor; $\sigma 38$ (RpoS): RNA polymerase sigma factor RpoS; $\sigma 54$ (RpoN): RNA polymerase sigma-54 factor; $\sigma 70$ (RpoD): RNA polymerase sigma factor; $\sigma$-factor(s): Sigma-factor(s); $\sigma-R N A$ : Sigma-RNA; A: Adenine; ABC: ATP-binding cassette; AcnA: Aconitate hydratase 1; AcrA/B: Acriflavine resistance protein A/B; AhpC: Alkyl hydroperoxide reductase subunit C; AP: Abasic; argB: N-acetyl-L-glutamate kinase gene; ATP: Adenosine triphosphate; BER: Base excision repair; BetA: Choline dehydrogenase BetA; BetB: Betaine aldehyde dehydrogenase BetB; BetT: High affinity choline transporter protein BetT; Bfr: Bacterioferritin; BHI: Brainheart infusion medium; Bp: Base pair; C: Cytosine; CadA: Cadmium efflux ATPase CadA; CDS(s): Coding sequences(s); Cnr: Nickel and cobalt resistance protein Cnr; CopA: Copper-exporting P-type ATPase A; CorA: Magnesium transport protein CorA; CPA: Monovalent cation/proton antiporter; CPA1/2/3: Monovalent cation/proton antiporter-1/2/3; Cpx: Cytochrome peroxidase $C$; CspA/D: Cold shock protein CspA/D; CstA/B: Carbon starvation-induced 
protein CstA/B; DNA: Deoxyribonucleic acid;DnaK: Chaperone protein DnaK; DppB/C: Dipeptide transport system permease protein DppB/C; DppD/F: Dipeptide transport ATP-binding protein DppD/F; Dps: Deoxyribonucleic acid protection during starvation protein; DSB(s): Double-strand break(s); DSBR: Double-strand break repair; dsDNA: Double-stranded deoxyribonucleic acid; DUE: DNA-unwinding element; dUMP: Deoxyuridine 5'-monophosphate; dUTP: Deoxyuridine 5'-triphosphate; FbpA: Major ferric iron-binding protein FbpA; FbpB: Ferric transport system permease protein FbpB; FbpC: Ferric ions import ATP-binding protein $\mathrm{FbpC}$; FeoA/B/C: Ferrous iron transport protein $A / B / C$; Fis: Factor for inversion stimulation; FNR: Fumarate and nitrate reduction regulatory proteins; Fpr: Ferredoxin-NADP reductase; FumC: Fumarase C; Fur: Furric uptake regulation protein Fur; G: Guanine; GlpF: Glycerol uptake facilitator protein; GlpK: Glycerol kinase GlpK; GlpR: Glycerol3-phosphate regulon repressor protein GlpR; Gor: Glutathione reductase; GO system: 8oxodG system; GpxA: Glutathione peroxidase; GrxA/C: Glutaredoxin1/3; GshA: Glutamate-cysteine ligase; GshB: Glutathione synthase; HoxN: High-affinity; nickel transport protein HoxN; HtpG: High temperature protein HtpG; IHF(s): Integration host factor(s); Kef: Glutathione-regulated potassium efflux protein Kef; KefB: Glutathione-regulated potassium efflux protein KefB; LB: Lysogeny broth; Lrp: Leucine-responsive regulatory protein; LysR: Transcriptional activator protein LysR; mg N/L: Milligrams of nitrogen per liter; mg O2/L: Milligrams of oxygen per liter; mg P/L: Milligrams of phosphorus per liter; MIT: Metal inorganic transport system; MMR: Mismatch repair; MopA: 60 kDa chaperonin; alternative name for GroEL or Cpn60; mRNA: Messenger ribonucleic acid; MutM: Formamidopyrimidine-DNA glycosylase; MutT: Mutator MutT protein; MutY: Adenine/thymine-specific adenine glycosylase; NAGK: N-acetyl-L-glutamate kinase; Ncc: Nickel-cobaltcadmium resistance protein Ncc; NER: Nucleotide excision repair; NfnB: Oxygen-insensitive NAD(P)H nitroreductase; NhaA/B/C/D: Sodium/proton antiporter NhaA/B/C/D; NicO/A: High-affinity nickel transport protein NicO/A; NiCoT: Nickel(II)-cobalt(II) uptake transporter; NlpD: Lipoprotein NIpD; NolG: Nodulation protein NolG; Nth: Endonuclease III; O: Oxygen; oriC: Origin of replication; OsmB/C: Osmotically-inducible lipoprotein OsmB/C; OxyR: Hydrogen peroxide-inducible genes regulator OxyR; Pcm: Protein-Lisoaspartate O-methyltransferase; PhoB: Phosphate regulon transcriptional regulatory protein PhoB; PhoR: Phosphate regulon sensor protein PhoR; PhoU: Phosphate transport system protein PhoU; PhrB:

Deoxyribodipyrimidine photo-lyase; PitA: Low-affinity inorganic phosphate transporter PitA; Pst: Phosphate-specific transport system; PstS/C/A/B: Phosphate-specific transport system protein S/C/A/B; RIDA: Regulatory inactivation of DnaA; RNA: Ribonucleic acid; RNAP: Deoxyribonucleic aciddirected ribonucleic acid polymerase; RpoS: RNA polymerase sigma factor RpoS; SodB: Superoxide dismutase SodB; SoxR: Redox-sensitive transcriptional activator SoxR; SSAP(s): Single-stranded deoxyribonucleic acid annealing protein(s); ssDNA: Single-stranded deoxyribonucleic acid; SspA/B: Stringent starvation protein SspA/B; SurA/E: Stationary-phase survival protein SurA/E; T: Thymine; TCRS: Two-component regulatory system; TLS: Translesion deoxyribonucleic acid synthesis; TolC: Outer membrane protein TolC; TRCF: Transcription-repair coupling factor; TrxA: Thioredoxin; TrxB: Thioredoxin reductase; UNG: Uracil deoxyribonucleic acid glycosylase; UreA/C/B: Urease subunit gamma/alpha/beta; UreE/F/G/D/I: Urease accessory protein UreE/F/ G/D/I; UV: Ultraviolet; UvrA/B/C/D: UvrABC nucleotide excision repair system protein A/B/C/D; XthA Exodeoxyribonuclease III; YggX: Ferrous-trafficking protein; ZntA: Lead, cadmium, zinc and mercury-transporting ATPase ZntA

\section{Acknowledgements}

This work is partly supported by the Research Grant Council Grant, Committee for Research and Conference Grant and University Development Fund, The University of Hong Kong; the HKSAR Research Fund for the Control of Infectious Diseases of the Health, Welfare and Food Bureau. We are grateful to support from the Genome Research Centre, The University of Hong Kong, and the generous support of Mrs. Carol Yu, Professor Richard Yu, Mr. Hui Hoy and Mr. Hui Ming in the genomic sequencing platform.

\section{Author details}

'State Key Laboratory of Emerging Infectious Diseases, Hong Kong. ${ }^{2}$ Research Centre of Infection and Immunology, The University of Hong Kong, Hong Kong. ${ }^{3} \mathrm{Carol}$ Yu Centre of Infection, The University of Hong Kong, Hong Kong. ${ }^{4}$ Department of Microbiology, The University of Hong Kong, Hong Kong. ${ }^{5}$ Faculty of Dentistry, The University of Hong Kong, Hong Kong.

\section{Authors' contributions}

PCYW, KYY and SKPL designed and supervised the study. RYYF, TCCH, GKMW, AKLT, JLLT, WC, RMW and SOTC annotated the genome. HT performed bioinformatics analysis. SKPL, RYYF, TCCH, RMW and PCYW drafted the manuscript. All authors corrected the manuscript. All authors read and approved the final manuscript.

\section{Competing interests}

The authors declare that they have no competing interests.

Received: 25 February 2011 Accepted: 14 June 2011 Published: 14 June 2011

\section{References}

1. Yuen KY, Woo PCY, Teng JLL, Leung KW, Wong MKM, Lau SKP: Laribacter hongkongensis gen. nov., sp. nov., a novel Gram-negative bacterium isolated from a cirrhotic patient with bacteremia and empyema. J Clin Microbiol 2001, 39:4227-4232.

2. Lau SKP, Woo PCY, Hui WT, Li MWS, Teng JLL, Que TL, Yung RWH, Luk WK, Lai RWM, Yuen KY: Use of cefoperazone MacConkey agar for selective isolation of Laribacter hongkongensis. J Clin Microbiol 2003, 41:4839-4841.

3. Woo PCY, Kuhnert P, Burnens AP, Teng JLL, Lau SKP, Que TL, Yau HH, Yuen $\mathrm{KY}$ : Laribacter hongkongensis: a potential cause of infectious diarrhea. Diagn Microbiol Infect Dis 2003, 47:551-556.

4. Woo PCY, Lau SKP, Teng JLL, Que TL, Yung RWH, Luk WK, Lai RWM, Hui WT, Wong SSY, Yau HH, Yuen KY: Association of Laribacter hongkongensis in community-acquired gastroenteritis with travel and eating fish: a multicentre case-control study. Lancet 2004, 363:1941-1947.

5. Woo PCY, Lau SKP, Teng JLL, Yuen KY: Current status and future directions of Laribacter hongkongensis, a novel bacterium associated with gastroenteritis and traveller's diarrhoea. Curr Opin Infect Dis 2005, 18:413-419.

6. Teng JLL, Woo PCY, Ma SSL, Sit THC, Ng LT, Hui WT, Lau SKP, Yuen KY: Ecoepidemiology of Laribacter hongkongensis, a novel bacterium associated with gastroenteritis. J Clin Microbiol 2005, 43:919-922.

7. Lau SKP, Woo PCY, Fan RYY, Lee RCM, Teng JLL, Yuen KY: Seasonal and tissue distribution of Laribacter hongkongensis, a novel bacterium associated with gastroenteritis, in retail freshwater fish in Hong Kong. Int J Food Microbiol 2007, 113:62-66.

8. Lau SKP, Lee LCK, Fan RYY, Teng JLL, Tse CWS, Woo PCY, Yuen KY: Isolation of Laribacterhongkongensis, a novel bacterium associated with gastroenteritis, from Chinese tiger frog. Int I Food Microbiol 2009, 129:78-82.

9. Feng JL, Yan H, Chowdhury N, Neogi SB, Yamasaki S, Shi L, Hu J, Chen Q: Identification and characterization of integron-associated antibiotic resistant Laribacter hongkongensis isolated from aquatic products in China. Int J Food Microbiol 2011, 144:337-341.

10. Lau SKP, Woo PCY, Fan RYY, Ma SSL, Hui WT, Au SY, Chan LL, Chan JYF, Lau ATK, Leung KY, Pun TCT, She HHL, Wong CY, Wong LLL, Yuen KY: Isolation of Laribacter hongkongensis, a novel bacterium associated with gastroenteritis, from drinking water reservoirs in Hong Kong. J Appl Microbiol 2007, 103:507-515.

11. Parkhill J, Wren BW, Mungall K, Ketley JM, Churcher C, Basham D, Chillingworth T, Davies RM, Feltwell T, Holroyd S, Jagels K, Karlyshev AV, Moule S, Pallen MJ, Penn CW, Quail MA, Rajandream MA, Rutherford KM, van Vliet AH, Whitehead S, Barrell BG: The genome sequence of the foodborne pathogen Campylobacter jejuni reveals hypervariable sequences. Nature 2000, 403:665-668.

12. Tettelin $H$, Saunders NJ, Heidelberg J, Jeffries AC, Nelson KE, Eisen JA, Ketchum KA, Hood DW, Peden JF, Dodson RJ, Nelson WC, Gwinn ML, DeBoy R, Peterson JD, Hickey EK, Haft DH, Salzberg SL, White O, Fleischmann RD, Dougherty BA, Mason T, Ciecko A, Parksey DS, Blair E, Cittone H, Clark EB, Cotton MD, Utterback TR, Khouri H, Qin H, et al: Complete genome sequence of Neisseria meningitidis serogroup B strain MC58. Science 2000, 287:1809-1815.

13. Brazilian National Genome Project Consortium: The complete genome sequence of Chromobacterium violaceum reveals remarkable and exploitable bacterial adaptability. Proc Natl Acad Sci USA 2003, 100:11660-11665.

14. Davidsen T, Tønjum T: Meningococcal genome dynamics. Nat Rev Microbiol 2006, 4:11-22. 
15. Duarte FT, Carvalho FM, Bezerra e Silva U, Scortecci KC, Blaha CA, Agnez Lima LF, Batistuzzo de Medeiros SR: DNA repair in Chromobacterium violaceum. Genet Mol Res 2004, 3:167-180.

16. Michaels ML, Cruz C, Grollman AP, Miller JH: Evidence that MutY and MutM combine to prevent mutations by an oxidatively damaged form of guanine in DNA. Proc Natl Acad Sci USA 1992, 89:7022-7025.

17. Fowler RG, White SJ, Koyama C, Moore SC, Dunn RL, Schaaper RM: Interactions among the Escherichia coli mutT, mutM, and mutY damage prevention pathways. DNA Repair (Amst) 2003, 2:159-173.

18. Eisen JA, Hanawalt PC: A phylogenomic study of DNA repair genes, proteins, and processes. Mutat Res 1999, 435:171-213.

19. Batty DP, Wood RD: Damage recognition in nucleotide excision repair of DNA. Gene 2000, 241:193-204.

20. Seeberg E: Reconstitution of an Escherichia coli repair endonuclease activity from the separated $u v r A+$ and $u v r B+/ u v r C+$ gene products. Proc Natl Acad Sci USA 1978, 75:2569-2573.

21. Black CG, Fyfe JA, Davies JK: Cloning, nucleotide sequence and transcriptional analysis of the uvrA gene from Neisseria gonorrhoeae. Mol Gen Genet 1997, 254:479-485.

22. Marti TM, Kunz C, Fleck O: DNA mismatch repair and mutation avoidance pathways. J Cell Physiol 2002, 191:28-41

23. Lamers $M H$, Perrakis A, Enzlin JH, Winterwerp HH, de Wind N, Sixma TK: The crystal structure of DNA mismatch repair protein MutS binding to a $\mathrm{G} \times$ T mismatch. Nature 2000, 407:711-717.

24. Richardson AR, Yu Z, Popovic T, Stojiljkovic I: Mutator clones of Neisseria meningitidis in epidemic serogroup A disease. Proc Natl Acad Sci USA 2002, 99:6103-6107.

25. Mehr IJ, Seifert HS: Differential roles of homologous recombination pathways in Neisseria gonorrhoeae pilin antigenic variation, DNA transformation and DNA repair. Mol Microbiol 1998, 30:697-710.

26. Kline KA, Sechman EV, Skaar EP, Seifert HS: Recombination, repair and replication in the pathogenic Neisseriae: the 3 R's of molecular genetics of two human-specific bacterial pathogens. Mol Microbiol 2003, 50:3-13.

27. Kline KA, Seifert HS: Role of the Rep helicase gene in homologous recombination in Neisseria gonorrhoeae. J Bacteriol 2005, 187:2903-2907.

28. Kuzminov A: Recombinational repair of DNA damage in Escherichia coli and bacteriophage lambda. Microbiol Mol Biol Rev 1999, 63:751-813.

29. Iyer LM, Koonin EV, Aravind L: Classification and evolutionary history of the single-strand annealing proteins, RecT, Redbeta, ERF and RAD52. BMC Genomics 2002, 3:8

30. Matsumoto T, Morimoto $Y$, Shibata N, Kinebuchi T, Shimamoto $N$ Tsukihara T, Yasuoka N: Roles of functional loops and the C-terminal segment of a single-stranded DNA binding protein elucidated by X-Ray structure analysis. J Biochem 2000, 127:329-335

31. Yuzhakov A, Kelman Z, O'Donnell M: Trading places on DNA-a three-point switch underlies primer handoff from primase to the replicative DNA polymerase. Cell 1999, 96:153-163.

32. Courcelle J, Khodursky A, Peter B, Brown PO, Hanawalt PC: Comparative gene expression profiles following UV exposure in wild-type and SOSdeficient Escherichia coli. Genetics 2001, 158:41-64.

33. Fyfe JA, Davies JK: Nucleotide sequence and expression in Escherichia coli of the recA gene of Neisseria gonorrhoeae. Gene 1990, 93:151-156.

34. Black CG, Fyfe JA, Davies JK: Absence of an SOS-like system in Neisseria gonorrhoeae. Gene 1998, 208:61-66.

35. Parkhill J, Achtman M, James KD, Bentley SD, Churcher C, Klee SR, Morelli G, Basham D, Brown D, Chillingworth T, Davies RM, Davis P, Devlin K, Feltwell T, Hamlin N, Holroyd S, Jagels K, Leather S, Moule S, Mungall K, Quail MA, Rajandream MA, Rutherford KM, Simmonds M, Skelton J, Whitehead S, Spratt BG, Barrell BG: Complete DNA sequence of a serogroup A strain of Neisseria meningitidis Z2491. Nature 2000, 404:502-506

36. Mott ML, Berger JM: DNA replication initiation: mechanisms and regulation in bacteria. Nat Rev Microbiol 2007, 5:343-354.

37. Schmid MB: More than just "histone-like" proteins. Cell 1990, 63:451-453.

38. Lorenz M, Hillisch A, Goodman SD, Diekmann S: Global structure similarities of intact and nicked DNA complexed with IHF measured in solution by fluorescence resonance energy transfer. Nucleic Acids Res 1999, 27:4619-4625.

39. Wold S, Crooke E, Skarstad K: The Escherichia coli Fis protein prevents initiation of DNA replication from oriC in vitro. Nucleic Acids Res 1996, 24:3527-3532
40. Hiasa H, Marians KJ: Fis cannot support oriC DNA replication in vitro. J Biol Chem 1994, 269:24999-25003

41. Kato J, Katayama T: Hda, a novel DnaA-related protein, regulates the replication cycle in Escherichia coli. EMBO J 2001, 20:4253-4262.

42. Camara JE, Skarstad K, Crooke E: Controlled initiation of chromosomal replication in Escherichia coli requires functional Hda protein. J Bacteriol 2003, 185:3244-3248

43. Woo PCY, Lau SKP, Tse H, Teng JLL, Curreem SOT, Tsang AKL, Fan RYY, Wong GKM, Huang Y, Loman NJ, Snyder LAS, Cai JJ, Huang JD, Mak W, Pallen MJ, Lok S, Yuen KY: The complete genome and proteome of Laribacter hongkongensis reveal potential mechanisms for adaptations to different temperatures and habitats. PLOS Genet 2009, 5:e1000416

44. Seputiene $V$, Motiejūnas D, Suziedelis $K$, Tomenius $H$, Normark $S$, Melefors $\mathrm{O}$, Suziedeliene E: Molecular characterization of the acidinducible asr gene of Escherichia coli and its role in acid stress response. J Bacteriol 2003, 185:2475-2484

45. Mates AK, Sayed AK, Foster JW: Products of the Escherichia coli acid fitness island attenuate metabolite stress at extremely low $\mathrm{pH}$ and mediate a cell density-dependent acid resistance. J Bacteriol 2007, 189:2759-2768

46. Foster JW, Bearson B: Acid-sensitive mutants of Salmonella typhimurium identified through a dinitrophenol lethal screening strategy. J Bacteriol 1994, 176:2596-2602

47. Chan YC, Blaschek HP: Comparative analysis of Shigella boydii 18 foodborne outbreak isolate and related enteric bacteria: role of rpoS and adiA in acid stress response. J Food Prot 2005, 68:521-527.

48. Lee IS, Lin J, Hall HK, Bearson B, Foster JW: The stationary-phase sigma factor sigma $S$ (RpoS) is required for a sustained acid tolerance response in virulent Salmonella typhimurium. Mol Microbiol 1995, 17:155-167.

49. Yang $Y$, Harris DP, Luo F, Wu L, Parsons AB, Palumbo AV, Zhou J: Characterization of the Shewanella oneidensis Fur gene: roles in iron and acid tolerance response. BMC Genomics 2008, 9(Suppl 1):11.

50. Padan $\mathrm{E}$, Bibi $\mathrm{E}$, Ito $\mathrm{M}$, Krulwich TA: Alkaline $\mathrm{pH}$ homeostasis in bacteria: new insights. Biochim Biophys Acta 2005, 1717:67-88

51. Krulwich TA, Hicks DB, Ito M: Cation/proton antiporter complements of bacteria: why so large and diverse? Mol Microbiol 2009, 74:257-260.

52. Ito M, Guffanti AA, Zemsky J, Ivey DM, Krulwich TA: Role of the nhaCencoded $\mathrm{Na}+/ \mathrm{H}+$ antiporter of alkaliphilic Bacillus firmus OF4. J Bacteriol 1997, 179:3851-3857.

53. Nies DH: Microbial heavy-metal resistance. Appl Microbiol Biotechnol 1999, 51:730-750.

54. Harrison PM, Arosio P: The ferritins: molecular properties, iron storage function and cellular regulation. Biochim Biophys Acta 1996, 1275:161-203.

55. Anderson DS, Adhikari P, Nowalk AJ, Chen CY, Mietzner TA: The hFbpABC transporter from Haemophilus influenzae functions as a binding-proteindependent $A B C$ transporter with high specificity and affinity for ferric iron. J Bacteriol 2004, 186:6220-6229.

56. Bauerfeind P, Garner RM, Mobley LT: Allelic exchange mutagenesis of nixA in Helicobacter pylori results in reduced nickel transport and urease activity. Infect Immun 1996, 64:2877-2880.

57. Morton DJ, Seale TW, Vanwagoner TM, Whitby PW, Stull TL: The dppBCDF gene cluster of Haemophilus influenzae: Role in heme utilization. BMC Res Notes 2009, 2:166.

58. Liesegang $H$, Lemke $K$, Siddiqui RA, Schlegel HG: Characterization of the inducible nickel and cobalt resistance determinant $\mathrm{cnr}$ from pMOL28 of Alcaligenes eutrophus CH34. J Bacteriol 1993, 175:767-778.

59. Schmidt T, Schlegel HG: Combined nickel-cobalt-cadmium resistance encoded by the ncc locus of Alcaligenes xylosoxidans 31A. J Bacteriol 1994, 176:7045-7054

60. Eitinger T, Suhr J, Moore L, Smith JA: Secondary transporters for nickel and cobalt ions: theme and variations. Biometals 2005, 18:399-405.

61. Kobayashi M, Shimizu S: Cobalt proteins. Eur J Biochem 1999, 261:1-9.

62. Rodionov DA, Hebbeln P, Gelfand MS, Eitinger T: Comparative and functional genomic analysis of prokaryotic nickel and cobalt uptake transporters: evidence for a novel group of ATP-binding cassette transporters. J Bacteriol 2006, 188:317-327.

63. Nucifora G, Chu L, Misra TK, Silver S: Cadmium resistance from Staphylococcus aureus plasmid pl258 cadA gene results from a cadmium-efflux ATPase. Proc Natl Acad Sci USA 1989, 86:3544-3548. 
64. Zhang Y, Zhang H, Li X, Su Z, Zhang C: The cadA gene in cadmiumresistant bacteria from cadmium-polluted soil in the Zhangshi area of Northeast China. Curr Microbiol 2008, 56:236-239.

65. Legatzki A, Grass G, Anton A, Rensing C, Nies DH: Interplay of the Czc system and two P-type ATPases in conferring metal resistance to Ralstonia metallidurans. J Bacteriol 2003, 185:4354-4361.

66. Rensing C, Sun Y, Mitra B, Rosen BP: Pb(II)-translocating P-type ATPases. J Biol Chem 1998, 273:32614-32617.

67. Rensing C, Mitra B, Rosen BP: The zntA gene of Escherichia coli encodes a Zn (II)-translocating P-type ATPase. Proc Natl Acad Sci USA 1997, 94:14326-14331.

68. Rensing C, Fan B, Sharma R, Mitra B, Rosen BP: CopA: An Escherichia coli Cu(I)-translocating P-type ATPase. Proc Natl Acad Sci USA 2000, 97:652-656.

69. Perozo $E$, Rees DC: Structure and mechanism in prokaryotic mechanosensitive channels. Curr Opin Struct Biol 2003, 13:432-442.

70. Sleator RD, Hill C: Bacterial osmoadaptation: the role of osmolytes in bacterial stress and virulence. FEMS Microbiol Rev 2002, 26:49-71.

71. Weissenborn DL, Wittekindt N, Larson TJ: Structure and regulation of the glpFK operon encoding glycerol diffusion facilitator and glycerol kinase of Escherichia coli K-12. J Biol Chem 1992, 267:6122-6131.

72. Jung JU, Gutierrez C, Villarejo MR: Sequence of an osmotically inducible lipoprotein gene. J Bacterio/ 1989, 171:511-520.

73. Gutierrez C, Devedjian JC: Osmotic induction of gene osmC expression in Escherichia coli K12. J Mol Biol 1991, 220:959-973.

74. Conter A, Gangneux C, Suzanne M, Gutierrez C: Survival of Escherichia coli during long-term starvation: effects of aeration, $\mathrm{NaCl}$, and the rpoS and osmC gene products. Res Microbiol 2001, 152:17-26.

75. Zeller T, Klug G: Thioredoxins in bacteria: functions in oxidative stress response and regulation of thioredoxin genes. Naturwissenschaften 2006, 93:259-266.

76. Mongkolsuk S, Helmann JD: Regulation of inducible peroxide stress responses. Mol Microbiol 2002, 45:9-15.

77. Fernandes AP, Holmgren A: Glutaredoxins: glutathione-dependent redox enzymes with functions far beyond a simple thioredoxin backup system. Antioxid Redox Signal 2004, 6:63-74.

78. Imlay JA: Celluar defenses againsts superoxide and hydrogen peroxide. Annu Rev Biochem 2008, 77:755-776.

79. Kiley PJ, Beinert H: Oxygen sensing by the global regulator, FNR: the role of the iron-sulfur cluster. FEMS Microbiol Rev 1998, 22:341-352.

80. Chen S, Rosner MH, Calvo JM: Leucine-regulated self-association of leucine-responsive regulatory protein (Lrp) from Escherichia coli. J Mol Biol 2001, 312:625-635.

81. Storz G, Imlay JA: Oxidative stress. Curr Opin Microbiol 1999, 2:188-194.

82. Seib KL, Wu HJ, Kidd SP, Apicella MA, Jennings MP, McEwan AG: Defenses against oxidative stress in Neisseria gonorrhoeae: a system tailored for a challenging environment. Microbiol Mol Biol Rev 2006, 70:344-361.

83. Personal communication (for data not available online). [http://www.wsd. gov.hk/en/water_resources/water_quality/water_quality_monitoring_data/ index.html].

84. Yamamoto K, Kato J, Yano T, Ohtake H: Kinetics and modeling of hexavalent chromium reduction in Enterobacter cloacae. Biotechnol Bioeng 1993, 41:129-133.

85. Finkel SE: Long-term survival during stationary phase: evolution and the GASP phenotype. Nat Rev Microbiol 2006, 4:113-120.

86. Pappachan A, Savithri HS, Murthy MR: Structural and functional studies on a mesophilic stationary phase survival protein (Sur E) from Salmonella Typhimurium. FEBS J 2008, 275:5855-5864.

87. Tidhar A, Flashner Y, Cohen S, Levi Y, Zauberman A, Gur D, Aftalion M, Elhanany E, Zvi A, Shafferman A, Mamroud E: The NIpD lipoprotein is a novel Yersinia pestis virulence factor essential for the development of plague. PLoS One 2009, 4:e7023.

88. Li C, Wu PY, Hsieh M: Growth-phase-dependent transcriptional regulation of the $p c m$ and surE genes required for stationary-phase survival of Escherichia coli. Microbiology 1997, 143:3513-3520.

89. Vertommen D, Ruiz N, Leverrier P, Silhavy TJ, Collet JF: Characterization of the role of the Escherichia coli periplasmic chaperone SurA using differential proteomics. Proteomics 2009, 9:2432-2443.

90. Schultz JE, Matin A: Molecular and functional characterization of a carbon starvation gene of Escherichia coli. J Mol Biol 1991, 218:129-140.

91. Williams MD, Ouyang TX, Flickinger MC: Starvation-induced expression of SspA and SspB: the effects of a null mutation in sspA on Escherichia coli protein synthesis and survival during growth and prolonged starvation. Mol Microbiol 1994, 11:1029-1043.

92. Correll DL: Phosphorus: a rate limiting nutrient in surface waters. Poult Sci 1999, 78:674-682

93. Pradeep Ram AS, Sime-Ngando T: Functional responses of prokaryotes and viruses to grazer effects and nutrient additions in freshwater microcosms. ISME J 2008, 2:498-509.

94. Gikas GD, Tsihrintzis VA, Akratos CS, Haralambidis G: Water quality trends in Polyphytos reservoir, Aliakmon River, Greece. Environ Monit Assess 2009, 149:163-181.

95. Wagner JK, Setayeshgar S, Sharon LA, Reilly JP, Brun WV: A nutrient uptake role for bacterial cell envelope extensions. Proc Natl Acad Sci USA 2006, 103:11772-11777.

96. Li Y, Zhang Y: PhoU is a persistence switch involved in persister formation and tolerance to multiple antibiotics and stresses in Escherichia coli. Antimicrob Agents Chemother 2007, 51:2092-2099.

97. Rifat D, Bishai WR, Karakousis PC: Phosphate depletion: a novel trigger for Mycobacterium tuberculosis persistence. J Infect Dis 2009, 200:1126-1135.

98. Wanner BL: Phosphorus assimilation and its control of gene expression in Escherichia coli. In The Molecular Basis of Bacterial Metabolism. Edited by: Hauska G, Thauer R. Springer-Verlag, Heidelberg; 1990:152-163, Cited in Lamarche et. al.

99. Lamarche MG, Wanner BL, Crépin S, Harel J: The phosphate regulon and bacterial virulence: a regulatory network connecting phosphate homeostasis and pathogenesis. FEMS Microbiol Rev 2008, 32:461-473.

100. Yu NY, Wagner JR, Laird MR, Melli G, Rey S, Lo R, Dao P, Sahinalp SC, Ester M, Foster LJ, Brinkman FS: PSORTb 3.0: improved protein subcellular localization prediction with refined localization subcategories and predictive capabilities for all prokaryotes. Bioinformatics 2010, 26:1608-1615.

doi:10.1186/2045-3701-1-22

Cite this article as: Lau et al:: Environmental adaptability and stress tolerance of Laribacter hongkongensis: a genome-wide analysis. Cell \& Bioscience 2011 1:22

\section{Submit your next manuscript to BioMed Central and take full advantage of:}

- Convenient online submission

- Thorough peer review

- No space constraints or color figure charges

- Immediate publication on acceptance

- Inclusion in PubMed, CAS, Scopus and Google Scholar

- Research which is freely available for redistribution

Submit your manuscript at www.biomedcentral.com/submit
C Biomed Central 